\title{
Understanding the Full Climate Change IMPACt OF ENERgy Consumption and Mitigation at the End-USE LeVEL: \\ A Proposed Methodology for Allocating IndiReCt CARBon DIOXIDE EMISSIONS
}

Stephane de la Rue du Can ${ }^{\mathrm{a}}$

Lynn Price $^{\mathrm{a}}$

Timm Zwickel ${ }^{\mathrm{b}}$

${ }^{a}$ Energy Analysis and Environmental Impacts Division

Energy Technologies Area

Lawrence Berkeley National Laboratory

1 Cyclotron Road, MS 90R2121

Berkeley, CA USA 94720

Email: sadelarueducan@lbl.gov

Phone: (1) 5104867762

${ }^{\mathrm{b}}$ Potsdam Institute for Climate Impact Research (PIK)

Telegraphenberg A 31

14473 Potsdam

Germany

\section{ABSTRACT}

This paper presents a methodology to allocate carbon dioxide $\left(\mathrm{CO}_{2}\right)$ emissions that result from fuel combusted to produce electricity and heat to the end-use sectors (industry, buildings, transport, and agriculture) where the electricity and heat are actually consumed. Attributing these indirect emissions to the appropriate sectors results in a very different picture of $\mathrm{CO}_{2}$ 
emissions per sector than is seen when only direct emissions are characterized. With attribution to the demand side, the industrial and buildings sectors contribute the largest shares of $\mathrm{CO}_{2}$ emissions globally. When indirect emissions are allocated to their respective enduse sectors, the buildings sector's share of total emissions increases the most, from 9\% (direct emissions only) to $31 \%$ (including indirect emissions), which reflects the large share of electricity and heat consumed in this sector. The share of $\mathrm{CO}_{2}$ emissions attributable to the industrial sector also increases significantly, from $18 \%$ to $37 \%$. These increased values include emissions from both electricity and heat used in end-use sectors, in contrast to the traditional accounting method, which allocates all electricity and heat emissions to the transformation and energy sector. Allocating these emissions to end-use sectors makes it possible to assess the full potential impact of demand reduction of electricity and heat use. This article is based on contributions to the Fifth Assessment Report of Working Group III of the Intergovernmental Panel on Climate Change.

Keywords: electricity emission factor, primary energy, power sector $\mathrm{CO}_{2}$ emissions, indirect emissions

\section{INTRODUCTION}

Carbon dioxide $\left(\mathrm{CO}_{2}\right)$ emissions from the production of electricity and heat represent the largest source of greenhouse gases (GHGs), comprising a quarter of all GHGs emitted in 2010 (IPCC, 2014; IEA, 2013a). Past trends demonstrate continuous growth of these emissions with an average annual growth rate of $3.2 \%$ during the period 2000 to 2010 , compared to $2.0 \%$ during the period 1990 to 2000.

Emissions from electricity and heat production are traditionally reported in the energy sector. However, the electricity and heat consumption leading to these emissions does not occur in the energy sector but in the end use sectors (industry, buildings, transportation, and agriculture). Even so, when electricity and heat consumption increases in a particular end use sector, the emissions reported in that sector do not increase but rather the emissions from the energy sector increase. Similarly, mitigation actions leading to the reduction of electricity and heat consumption in the end use sectors are not reported as lower emissions in those sectors where the reductions actually occur.

This traditional reporting approach does not provide a complete picture of emissions resulting from the energy consumption in the end use sectors. This paper outlines a complementary approach for GHG emissions reporting that accounts for indirect emissions from electricity and heat in the end use sectors where they are ultimately consumed. For this accounting approach, it could be considered that the emissions from the energy sector are re-allocated to the end use sectors. This re-allocation of indirect $\mathrm{CO}_{2}$ emissions from electricity and heat consumption is a 
means for accounting for these emissions in the end use sectors where electricity and heat are ultimately consumed. This re-allocation provides a more complete picture of the emissions resulting from total energy consumption in each end-use sectors and allows for better mitigation policy prioritization across end use sectors. At the global level, indirect emissions were reported at the end use level in two chapters of the 2007 IPCC Fourth Assessment Report (AR4), Chapter 6: Residential and Commercial Buildings (Levine et al., 2007) and Chapter 7: Industry (Bernstein et al., 2007) and the methodology used was documented in de la Rue du Can and Price (2008). The International Energy Agency (IEA) reports $\mathrm{CO}_{2}$ emissions with electricity and heat allocated to consuming sectors but at an aggregate level with no sectoral detail (IEA, 2013a).

Only a few countries report indirect emissions in their national inventories. The U.S. Environmental Protection Agency (EPA) calculates and reports end-use indirect emissions from only electricity consumption (US EPA, 2014). The UK National Atmospheric Emissions Inventory (NAEI) uses an end-user model to allocate all emissions resulting from the energy sector to the end use sectors and this approach has recently been adopted by the European Environment Agency (EEA) (UK DECC, 2014; EEA, 2012).

Indirect emissions are reported in several studies to show the importance of electricity related emissions in end use sectors. For example, Ou et al. (2011) provides a detailed analysis of the indirect emissions for China which accounts for all upstream stages of the electricity delivery process including resource extraction and transportation, feedstock production and transportation, power generation, and transmission and distribution (T\&D). Kannan et al. (2009) shows the need to consider the interaction of the power sector and end use sectors when modeling and building reduction strategies in the UK. At the local level, Chen and Chen (2012 and 2015) use the concept of urban metabolism to analyze the energy and material flows of cities in a quest for a better understanding of sustainable urban systems.

In recent years there has been growing interest in the emissions trade balances of countries. $A$ number of researchers have developed consumption-based inventories at the national, regional, and global levels (e.g. Davis and Caldeira, 2010; Davis et al., 2010; Peters, 2010; Homma et al., 2012; Shigeto, 2012; Gavrilova and Vilu, 2012; Feng and Davis, 2012; Caro et al., 2014; Yuan et al., 2015). These consumption-based inventories use input-output tables to estimate GHG emissions occurring both within and outside national boundaries due to the country's consumption of goods, whether produced domestically or traded bilaterally. This approach further extends the boundaries of indirect $\mathrm{CO}_{2}$ emissions to account for emissions from the energy used in the production of goods and services consumed in a country but produced in another country. It should be noted that the methodology described in this paper is different from consumption-based inventories. The consumption-based inventory approach 
adds a geographical perspective and helps to better understand the implications of emissions related to trade. The accounting approach described in this paper does not re-allocate emissions across countries but rather re-allocates emissions across end-use sectors of a national economy, from the country's energy sector to the final buildings, industry, and transportation sectors within the country where energy is ultimately consumed to better understand the emissions implications of end-use sector activities. The methodology described in this paper is limited to indirect emissions occurring during electricity and heat production.

Several studies have described methodologies to estimate emission factors to calculate E\&H indirect emissions. Soimakallio and Saikku (2012) calculated production- and consumptionbased $\mathrm{CO}_{2}$ emission intensities of electricity for the Organization for Economic Co-operation and Development (OECD) countries from 1990 to 2008 and examined the impact of annual developments, allocation procedures for $\mathrm{CHP}$ production, and electricity trade in $\mathrm{CO}_{2}$ emissions. Brander et al. (2011) calculated electricity-specific emission factors for OECD and non-OECD countries and explained the limitations of the IEA composite electricity/heat factors. Marnay et al. (2002) and Harmsenn and Graus (2013) incorporated a temporal dimension in estimating $\mathrm{CO}_{2}$ emission from electricity savings by calculating marginal $\mathrm{CO}_{2}$ intensities based on peak power emissions intensity.

While the approach of calculating indirect emissions is well-known and a large number of papers can be found in the literature, the approach is still rarely applied at the national level and no paper exists describing the methodology for applying the approach globally. In a world where national governments are committing to and implementing emission reduction actions for mitigation of climate change, improving the understanding of how emissions are evolving is essential to better prioritize and maximize efforts. Moreover, a common and consistent methodology is essential for comparing actions and tracking progress.

The goal of this paper is to (1) demonstrate the significance of including electricity and heat indirect emissions in each end-use sector globally, (2) provide electricity-specific and heatspecific factors for 138 countries so that other researchers can use this methodology to account for the indirect emissions associated with end-use sectors, and (3) contribute to the discussion regarding developing a standard methodology to calculate indirect emissions for allowing comparison of country's sectoral-level commitments. This paper describes in detail the methodology used to allocate indirect $\mathrm{CO}_{2}$ emissions from electricity and heat production to the end-use sectors in the Fifth Assessment Report (AR5) of Working Group III of the Intergovernmental Panel on Climate Change (Krey et al., 2014).

Understanding the combined direct and indirect $\mathrm{CO}_{2}$ emissions associated with each end-use sector provides more robust information for researchers and policy makers to assess and monitor sectoral emissions trends, to identify and prioritize mitigation strategies, and to 
allocate resources to those sectors where the "demand" for energy - and thus the sectors responsible for these energy-related $\mathrm{CO}_{2}$ emissions - occur.

\section{DATA AND METHOdology}

To allocate energy-related $\mathrm{CO}_{2}$ emissions to the sectors where the electricity and heat consumption occurs, electricity emission factors and heat emission factors (the ratio of $\mathrm{CO}_{2}$ emissions per unit of electricity or heat delivered) were derived.

The data required to calculate $\mathrm{CO}_{2}$ emission factors are: fuel input $(\mathrm{I})$ and output ( $\left.\mathrm{E}_{\text {produced }}\right)$ to power, heat, and combined heat and power (CHP) plants; power plants' own energy consumption ( $E_{\text {own use); }}$ and distribution and transformation losses ( $\left.E_{\text {delivery loss }}\right)$. These data were gathered from the IEA for 138 countries (IEA, 2013b). Default emission factors ( $\mathrm{FF}_{\text {fuel }}$ ) in tonnes of $\mathrm{CO}_{2}$ per terajoule (TJ) for each type of fuel $f$ were gathered from the IPCC inventory guidelines (IPCC, 2006; see Appendix A for the complete list of emission factors used). Using these data, electricity $\left(E F_{E I}\right)$ and heat $\left(E F_{H}\right) C_{2}$ emissions factors (unit: $\mathrm{tCO}_{2} / \mathrm{TJ}$ ), i.e., the quantity of $\mathrm{CO}_{2}$ emitted for the delivery of one unit of electricity or heat, were calculated. The emission factors for electricity $\left(E F_{E I}\right)$ and heat $\left(E F_{H}\right)$ were computed for each country annually from 1971 to 2010 as follows:

$$
\mathrm{EF}(o, c, t)=\frac{\sum_{\mathrm{f}, \mathrm{p}} \mathrm{I}(o, c, t, f, p) \mathrm{EF}_{\text {fuel }}(f)}{\sum_{p}\left(\mathrm{E}_{\text {produced }}(o, c, t, p)\right)-\mathrm{E}_{\text {own use }}(o, c, t)-\mathrm{E}_{\text {delivery loss }}(o, c, t)}
$$

with output $o$ (either electricity or heat), country $c$, time $t$, fuel type $f$, plant type $p$.

Indirect $\mathrm{CO}_{2}$ emissions (IE) embodied in electricity and heat consumption were then estimated by multiplying the amount of final electricity and heat consumed in each sector ( $s$ ) by the $\mathrm{EF}_{\mathrm{EI}}$ and $\mathrm{EF}_{\mathrm{H}}($ Annex C), respectively, for each of the 138 countries and for every year from 1970 to 2010.

The indirect emissions (IE) were then computed by multiplying the emissions factors with the corresponding electricity and heat used $(E)$ by sector $s$, country $c$ and for each year $t$ :

$$
\operatorname{IE}(s, c, t)=\sum_{o} E F(o, c, t) E(s, o, c, t)
$$

\subsection{Accounting Conventions}


CHP plants produce two types of outputs, electricity and heat, from one type of energy input. To calculate heat and electricity specific factors, it is therefore necessary to estimate the share of energy input that results in the production of heat from the share that results in the production of electricity.

Fuel inputs (I) for electricity produced in CHP plants were separated from fuel inputs for heat production according to the fixed-heat-efficiency approach used by the IEA (IEA, 2013a). This approach fixes the efficiency for heat production equal to $90 \%$, which is the typical efficiency of a heat boiler. The input for heat production was calculated based on this efficiency and then subtracted it from total CHP input. The remaining input to CHP was assumed to be the input for electricity production.

$$
\begin{gathered}
\mathrm{I}(\text { heat }, C H P, c, t)=\frac{\mathrm{E}_{\text {produced }}(\text { heat }, c, t, C H P)}{90 \%} \\
\mathrm{I}(\text { electricity, } C H P, c)=\mathrm{I}(\text { total }, C H P, c)-\mathrm{I}(\text { heat }, C H P, c)
\end{gathered}
$$

As noted by the IEA, this approach may overstate the actual heat efficiency in certain circumstances (IEA, 2013a,b). Graus and Worrell's (2011) comparison of five methods for allocating inputs to heat and electricity production found that the method chosen can have a large impact on the $\mathrm{CO}_{2}$ intensity for countries that have relatively large amounts of $\mathrm{CHP}$, such as Russia, Germany, and Italy.

\subsection{AdJUSTMENTS AND ESTIMATIONS}

Several modifications were made to the original time series to address data issues. The source data were remapped between countries to have a constant set of countries cover the entire timespan (1970-2010). This affected the data of countries belonging to the former Soviet Union and former Yugoslavia. See Appendix B for additional details.

The IEA energy statistics report final energy and electricity use for three end-use sectors: industry, transport, and other. The "other" category is further subdivided into agriculture, fishing, commercial and public services, residential, and non-specified other. The "non-specified other" category includes energy used for agriculture, fishing, commercial and public services, and residential sectors that has not been allocated to these end-use sectors by the submitting countries. In most cases, there is no entry in the non-specified other category, indicating that all end-use energy consumption has been allocated to other end-use sectors. However, for some countries the energy reported in the non-specified other category needed to be allocated to the appropriate end-use sectors. To perform this allocation, the energy use in the non-specified other category was allocated to the other end-use sectors based on the share of energy allocated to each of these sub-sectors for each region. 
In this analysis, a domestic-based $\mathrm{CO}_{2}$ emissions factor was used to calculate emissions from electricity consumption in each end-use sector without distinguishing between domestically produced or imported electricity. The calculated emissions therefore represent the amount of $\mathrm{CO}_{2}$ that would have been emitted if all the electricity consumed had been produced domestically, using the existing domestic fuel mix. Therefore, countries that import a significant proportion of their total electricity consumption have higher overall emissions in this analysis than in the IEA statistics because their emissions include emissions also associated with their imported electricity. Similarly, countries that export electricity tend to have lower total emissions in this analysis than in the IEA statistics because only emissions for electricity consumption in that country are included in this analysis whereas the IEA statistics account for total production, including the portion that is exported. These differences tend to balance out at the global level.

Optimally, a consumption-based $\mathrm{CO}_{2}$ emissions factor should reflect the fuel mix of the imported electricity. However, this requires data on the origin and destination of exports; these data are not readily available for the 138 countries considered in this study. Moreover, electricity trading among countries is limited. In 2010, trade of electricity represented $3.3 \%$ of final electricity consumption in the world.

\subsection{COMPARISON WITH RePORTED IEA EMISSIONS}

\subsubsection{COMPARISON OF INDIRECT EMISSIONS WITH IEA EMISSIONS FROM ELECTRICITY AND HEAT PRODUCTION} Indirect $\mathrm{CO}_{2}$ emissions from electricity and heat production calculated using the methodology described above were compared with the reported IEA direct emissions from the electricity and heat sector. An average difference of $+1.36 \%$ over the years 1971 to 2010 was found, indicating that the calculation method used in this paper slightly overestimates indirect global $\mathrm{CO}_{2}$ emissions. This difference varies by year, with the largest negative difference in 1976 (-2.99\%) and the largest positive difference in 1990 (+3.23\%). However, these differences are more important at the country level, mainly as a result of import and export of electricity as

explained previously. Statistical differences between electricity delivered and electricity consumed in IEA energy statistics can also explained some of these differences.

\subsubsection{COMPARISON OF INDIRECT EMISSIONS WITH IEA INDIRECT EMISSIONS}

The IEA allocates total $\mathrm{CO}_{2}$ emissions from electricity and heat generation to the final energyconsuming sectors in proportion to the electricity and heat consumed without distinguishing emissions due to heat consumption from emissions due to electricity consumption. Table 1 compares the IEA indirect emissions with the indirect emissions calculated using the method described in this paper, showing that overall the differences are relatively small. The sectors that use large quantities of heat are attributed a lower share of emissions in the methodology used in this paper since heat production results in much lower $\mathrm{CO}_{2}$ emissions than electricity 
production. This is the case of the energy sector. This sector has globally the largest share of heat use where $37 \%$ of total electricity and heat consumed is heat.

\begin{tabular}{|l|r|r|r|}
\hline & \multicolumn{1}{|c|}{ IEA } & IPCC (AR5) & Difference \\
\hline Manufacturing & 4,980 & 5,318 & $6.8 \%$ \\
\hline Energy & 605 & 535 & $-11.6 \%$ \\
\hline Transport & 157 & 150 & $-4.8 \%$ \\
\hline Other & 6,738 & 6,536 & $-3.0 \%$ \\
\hline Total & 12,481 & 12,538 & $0.5 \%$ \\
\hline
\end{tabular}

Table 1. Indirect Emissions according to the IEA and IPCC (AR5) allocation methods $\left(\mathrm{Mt} \mathrm{CO}_{2}\right)$

\section{RESULtS}

\subsection{EMISSION FACTORS}

Figure 2 shows the distribution of the electricity $\mathrm{CO}_{2}$ emissions factors in blue and the heat $\mathrm{CO}_{2}$ emissions factors in orange, calculated for 138 countries for the years 1970, 2000, and 2010.

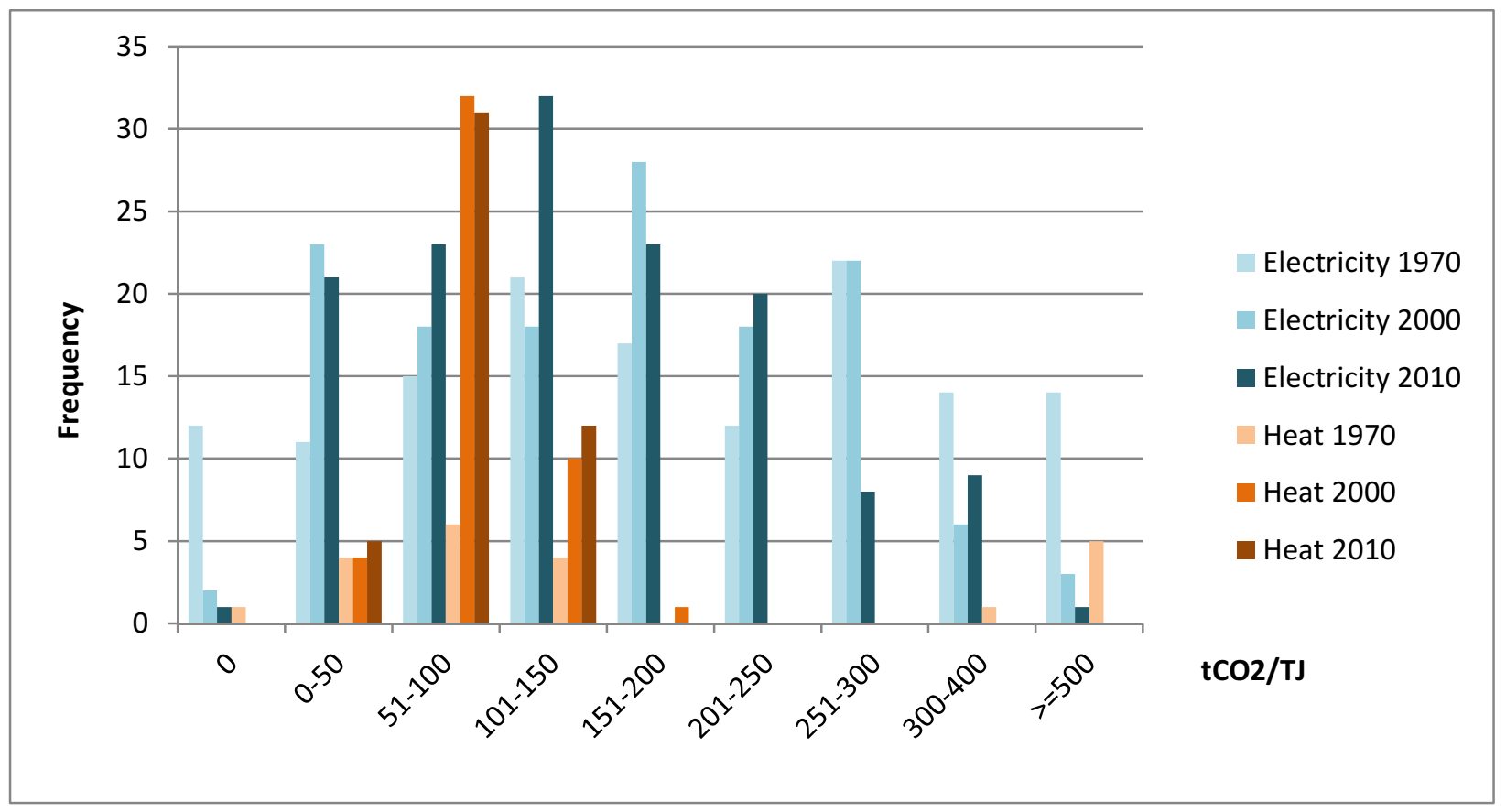

Figure 1. Electricity and Heat Emissions Factor Distribution across Countries for 1970, 2000, and 2010

The electricity $\mathrm{CO}_{2}$ factors indicate the $\mathrm{CO}_{2}$ emitted per unit of electricity delivered. These factors reflect the fuel mix in the power sector, the efficiency of power generation in all plants (electricity only and CHP), and electricity transmission and distribution (T\&D) losses. A country 
that uses a high share of non-fossil fuels for power generation will have a low electricity $\mathrm{CO}_{2}$ factor. Paraguay, Iceland, and Mozambique have the lowest electricity $\mathrm{CO}_{2}$ factors in the world - close to zero - because most of their electricity production comes from hydroelectric or geothermal plants. The quality of data available across countries is also reflected in these factors and can explain some of the observed outliers. For example, the electricity emission factor for Botswana in 2010 was $854 \mathrm{tCO}_{2} / \mathrm{TJ}(3,074 \mathrm{~g} / \mathrm{kWh})$. This value is much higher than any other country's value because of reporting issues in the IEA statistics; reported electricity production is 7 times lower in energy terms than the input for electricity production.

Depending on the country and the accounting methodology, emission factors for one unit of electricity range between 0 and $300 \mathrm{tCO}_{2} / \mathrm{TJ}$ in $93 \%$ of the cases in 2010 . The mean and median are $152 \mathrm{tCO}_{2} / \mathrm{TJ}$ and $140 \mathrm{tCO}_{2} / \mathrm{TJ}$ in 2010, respectively. The distribution shows a wide range of emission factors with an average deviation from the mean of $108 \mathrm{tCO}_{2} / \mathrm{TJ}$.

Heat emission factors for 2010 are also shown, in orange, on Figure 2. They are, on average, lower than electricity emissions factors, reflecting that less energy was needed to convert energy into heat than into electricity. Moreover, there are fewer emission factors because only 48 countries reported heat ${ }^{1}$ production from either CHP or heat plants in 2010 . Heat emission factors vary between 18 and $150 \mathrm{tCO}_{2} / \mathrm{TJ}$, with a mean of $81 \mathrm{tCO}_{2} / \mathrm{TJ}$ and a median $79 \mathrm{tCO} / \mathrm{TJ}$ in 2010. In earlier years, there are more outliers because of data reporting issues.

To observe trends across all countries, the same method explained previously was applied to world data to calculate global electricity and heat $\mathrm{CO}_{2}$ emission factors. Figure 3 shows the historical trends of these global factors. The emission factor for natural gas, $56.1 \mathrm{tCO}_{2} / \mathrm{TJ}$, is also shown for comparison.

\footnotetext{
${ }^{1}$ Note that only heat sold to a third party is reported in the IEA Statistics. Heat used by an auto-producer for the producer's own use is not reported.
} 


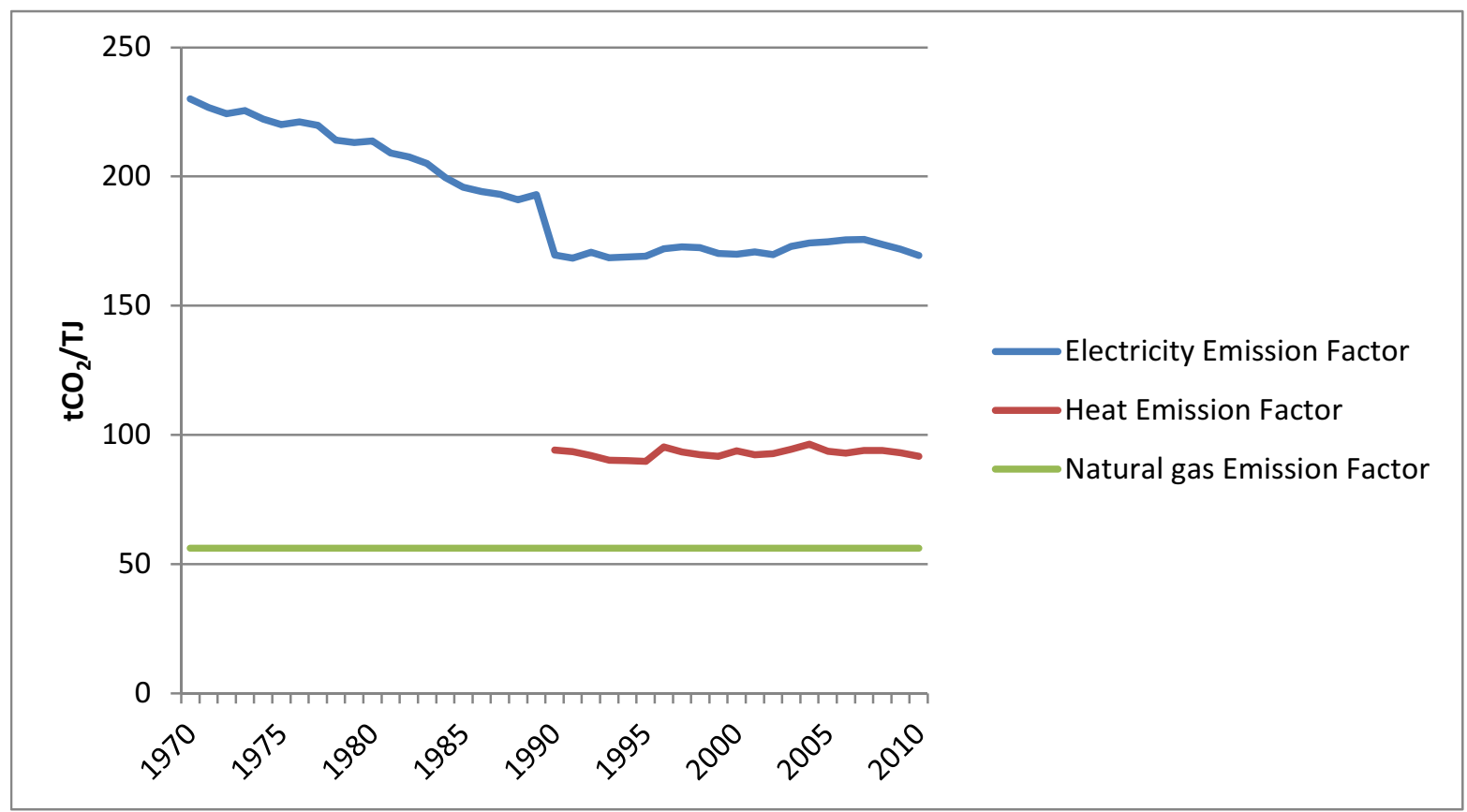

Source: Krey et al., 2014

Figure 2. Historical Electricity and Heat $\mathrm{CO}_{2}$ Emission Factors

The global electricity $\mathrm{CO}_{2}$ emissions factor was calculated to be $169.42 \mathrm{tCO}_{2} / \mathrm{TJ}$ in 2010 , very close to its level in 2000 (169.86 tCO $2 / T J)$ and in 1990 (169.68 tCO $2 / T J)$, meaning that the global carbon intensity of electricity delivered has remained fairly constant over the last 20 years. A large decrease can be observed following the collapse of the Soviet Union in 1989 when many inefficient power and heat plants were closed. This large decrease is also due to data issues, from moving to one region before 1990 to several independently-reporting countries starting in 1990. A smaller downward trend can be observed over the last 3 years due to the increase in renewables and the increase in the energy efficiency of power plants.

Figure 2 also highlights that electricity is much more carbon intensive on a global scale than natural gas; the latter can be consumed directly by end users with minimal energy consumption required for its delivery to consumers.

The global carbon emissions intensity of heat consumption has remained essentially flat since 1990. It was $94.14 \mathrm{tCO}_{2} / \mathrm{TJ}$ in 1990 , and it is $91.74 \mathrm{tCO}_{2} / \mathrm{TJ}$ in 2010.

At the country level, emissions factors vary widely. Figure 3 shows electricity $\mathrm{CO}_{2}$ emission factors for a selected number of countries. Countries that rely heavily on fossil fuels, especially coal, and where a significant share of electricity is lost during T\&D, have high electricity $\mathrm{CO}_{2}$ 
emission factors. This is the case for India, for example, where the electricity $\mathrm{CO}_{2}$ emissions $\mathrm{f}$ actor calculated is $362 \mathrm{tCO}_{2} / \mathrm{TJ}(1,303 \mathrm{~g} / \mathrm{kWh})$ in 2010, due to low power plant efficiency, a large share of electricity produced from coal, and very high T\&D loses. On the other side of the spectrum, Brazil has a relatively low electricity emission factor of $106 \mathrm{tCO}_{2} / \mathrm{TJ}$ (381 $\mathrm{g} / \mathrm{kWh}$ ) because $78 \%$ of Brazil's electricity is from hydropower plants. Theincrease in electricity $\mathrm{CO}_{2}$ emissions in India until 2000 is mostly due to low power plant efficiency. Electricity and heat emissions factors for all countries for 2010 are provided in Appendix C.

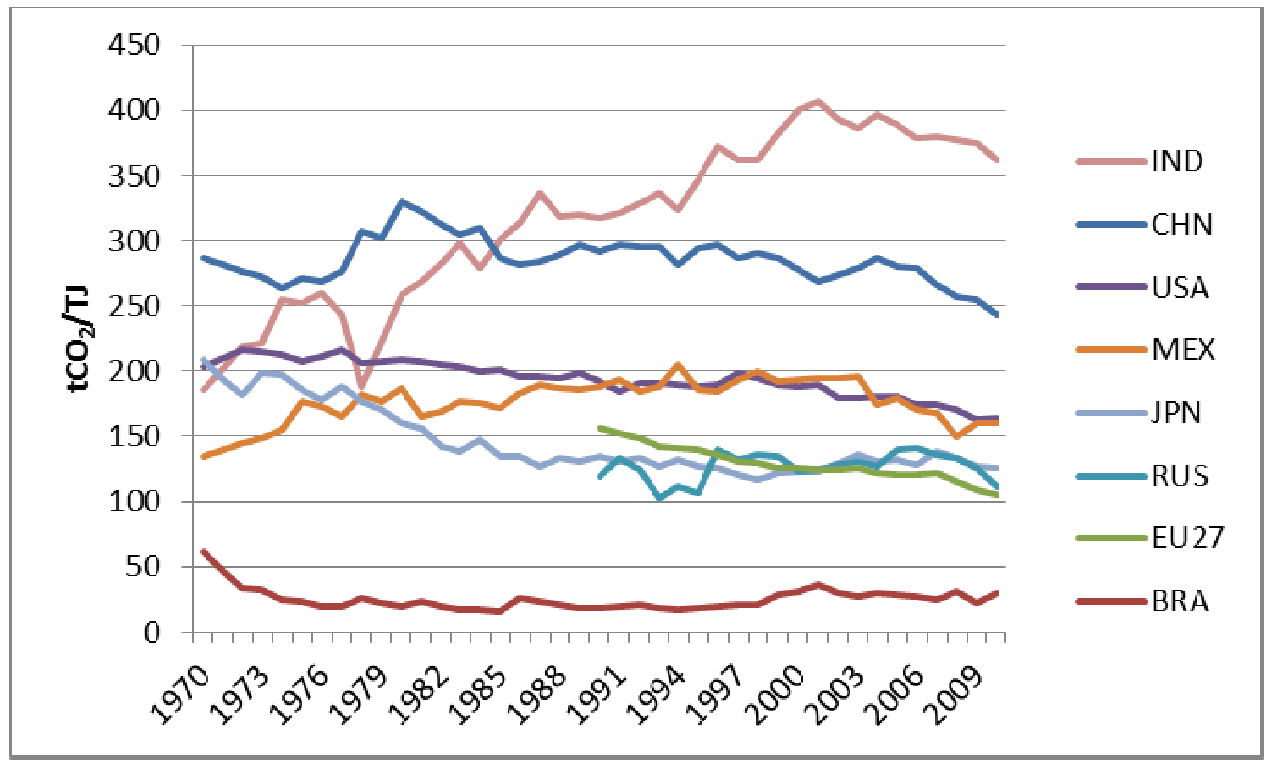

Figure 3: Electricity $\mathrm{CO}_{2}$ Emission Factors for Selected Countries

\subsection{INDIRECT EMISSIONS}

The calculated emission factors for electricity and heat at the country level are used to calculate indirect emissions from consumption of electricity and heat in the end-use sectors. Figure 4 shows the emissions from the electricity and heat sectors when distributed to the end-use sectors at the global level for 2010.

As the figure shows, not all emissions from the energy sector are allocated to the end-use sectors. The remaining emissions are from combustion of fuel for converting primary energy into other secondary energy sources such as refining oil or production of coal products such as coke. 


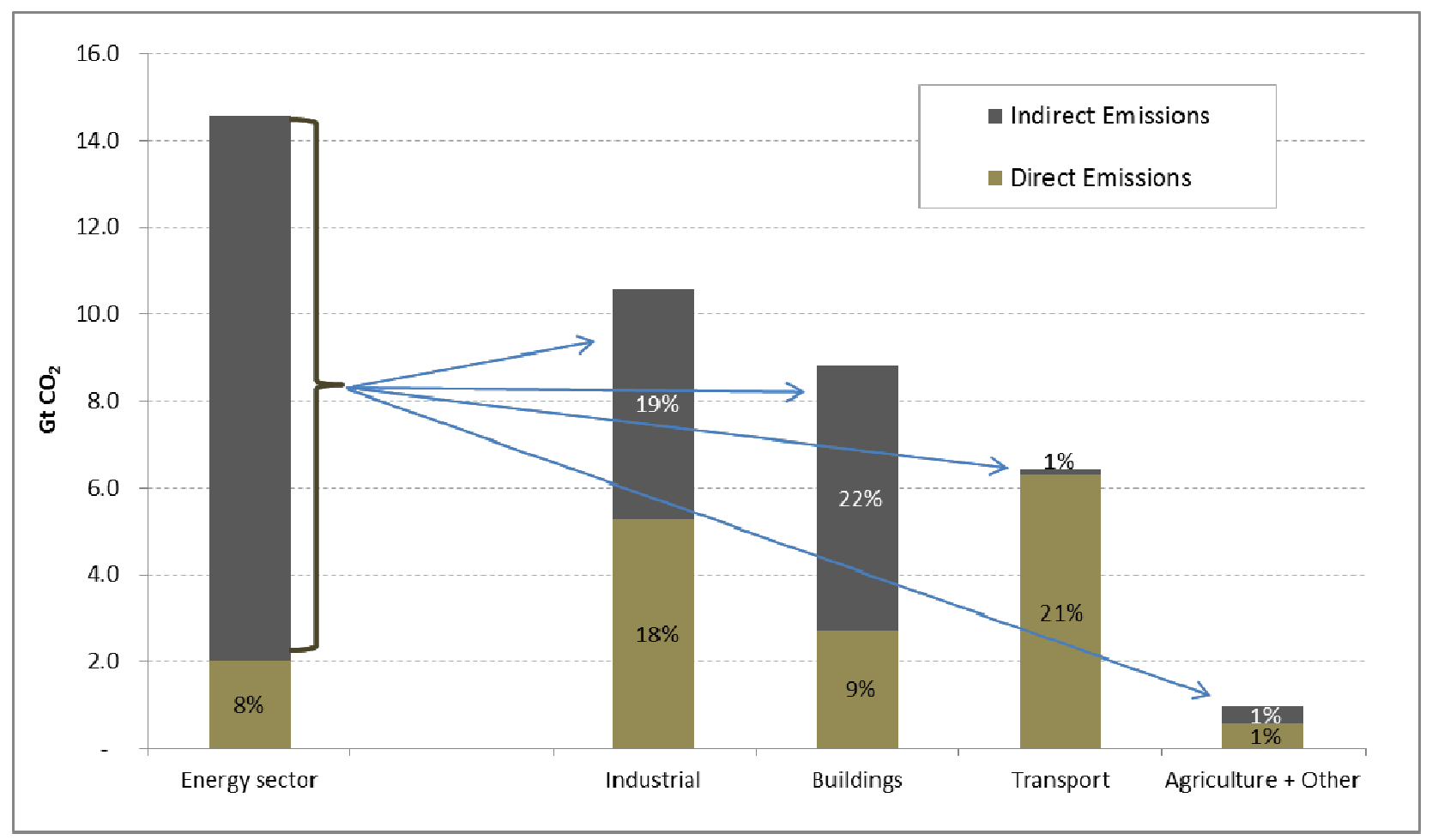

Source: Krey et al., 2014

Figure 4. Direct and Indirect Global Energy-Related $\mathrm{CO}_{2}$ Emissions from Fuel Combustion, 2010

The IEA's global sectoral emissions estimates show the energy sector as the largest source of $\mathrm{CO}_{2}$ emissions from fuel combustion. However, when indirect emissions are calculated as described above, the bulk of the emissions traditionally attributed to the energy sector are allocated to the buildings and industrial sectors. As a result, these two sectors are responsible for significant levels of combined direct and indirect $\mathrm{CO}_{2}$ emissions. The buildings sector's share of total emissions increases from $9 \%$ when only direct emissions are included to $31 \%$ when indirect emissions are added, reflecting the high share of electricity and heat demand in this sector. The share of $\mathrm{CO}_{2}$ emissions from the industrial sector also increases significantly, from $18 \%$ to $37 \%$, when emissions from production of the electricity and heat used by this sector are included. The transport and agriculture ${ }^{2}$ sectors' shares of emissions increase by a very small amount from $21 \%$ to $22 \%$ and $1 \%$ to $2 \%$, respectively. Thus, the calculation and allocation of indirect emissions results in a very different picture of the sectoral breakdown of $\mathrm{CO}_{2}$ emissions than the breakdown of only direct emissions. Using the allocation method described in this paper, industry and buildings are shown to be the largest sources of global $\mathrm{CO}_{2}$ emissions.

\footnotetext{
${ }^{2}$ Including emissions from fishing activities
} 
Figure 5 shows the share of indirect emissions from fuel combustion in total anthropogenic GHG emissions. The inner circle shows global direct GHG emission shares of five economic sectors in 2010, including GHG emissions from electricity and heat production; agriculture, forestry and other land use (AFOLU); buildings; transport; industry; and other energy. ${ }^{3}$ The side pull-out shows how indirect $\mathrm{CO}_{2}$ emission shares (in \% of total anthropogenic GHG emissions) from electricity and heat production are attributed to the final energy use sectors.

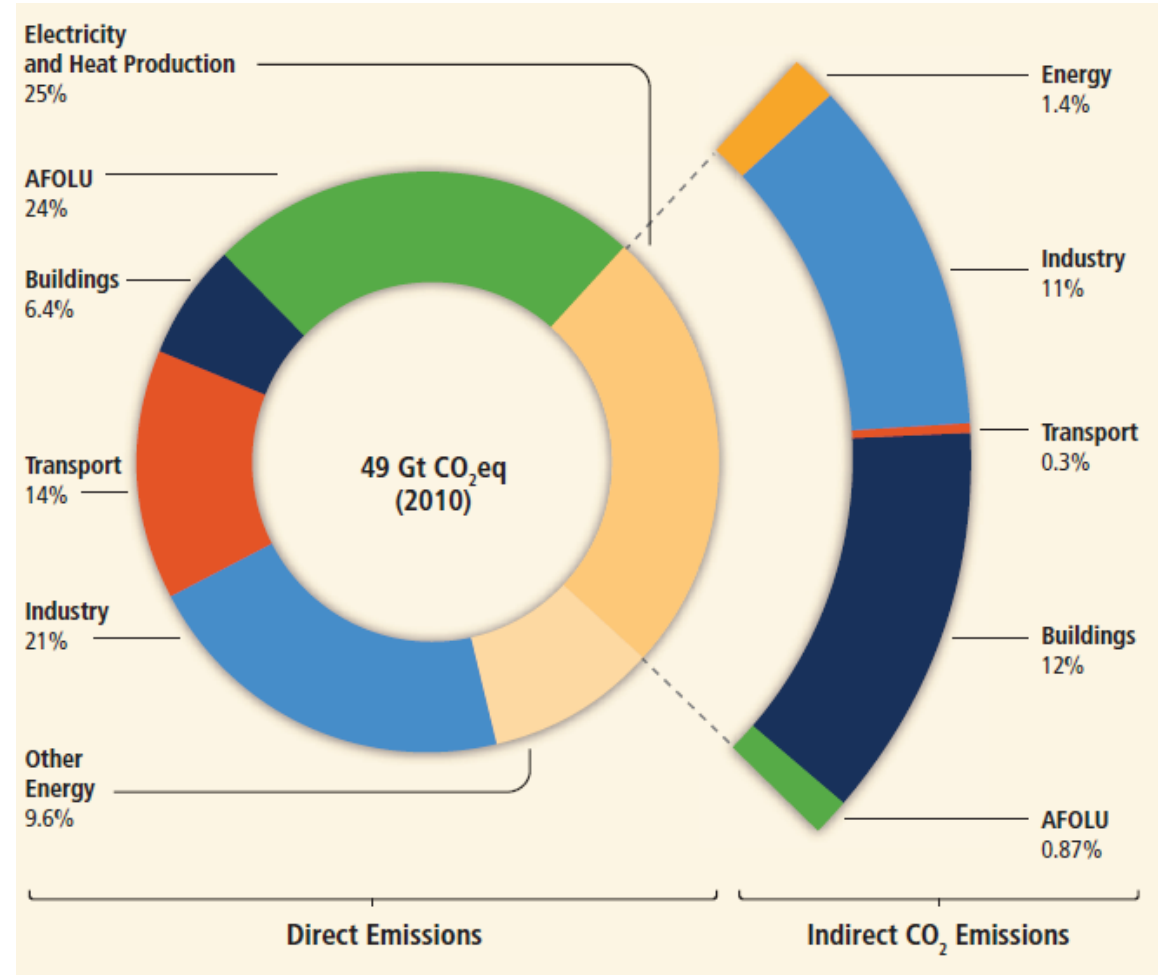

Source: IPCC, 2014

Note: Includes all GHGs, not just energy-related $\mathrm{CO}_{2}$ emissions

Figure 5. Total Anthropogenic GHG Emissions $\left(\mathrm{GtCO}_{2} \mathrm{eq} / \mathrm{yr}\right)$ by Economic Sectors

\section{END-USE INDIRECT EMISSIONS TRENDS}

\subsection{INDUSTRY}

Direct and indirect $\mathrm{CO}_{2}$ emissions from fuel combustion for the industrial sector accounted for 10.6 gigatons $(\mathrm{Gt})$ of $\mathrm{CO}_{2}$ emissions in 2010. This represents $68 \%$ of all GHG emissions from that sector when process and waste emissions are included (IPCC, 2014). Total $\mathrm{CO}_{2}$ emissions from the industrial sector have increased over the last 10 years at an average annual growth rate (AAGR) of 3.4\%, faster than during the previous 10 years (1990-2000) when the AAGR was

\footnotetext{
${ }^{3}$ Refers to all GHG emission sources in the energy sector as defined in Annex II of the IPCC AR5
} 
$0.3 \%$. The AAGR of indirect emissions increased slightly faster $(3.6 \%)$ than direct emissions (3.2\%) between 2000 and 2010, reflecting a more rapid increase in electricity use than in fuel use in this sector. Figure 6 shows historical direct and indirect industrial $\mathrm{CO}_{2}$ emissions from fuel combustion broken down into five world regions (see Appendix B for definition of the regions).

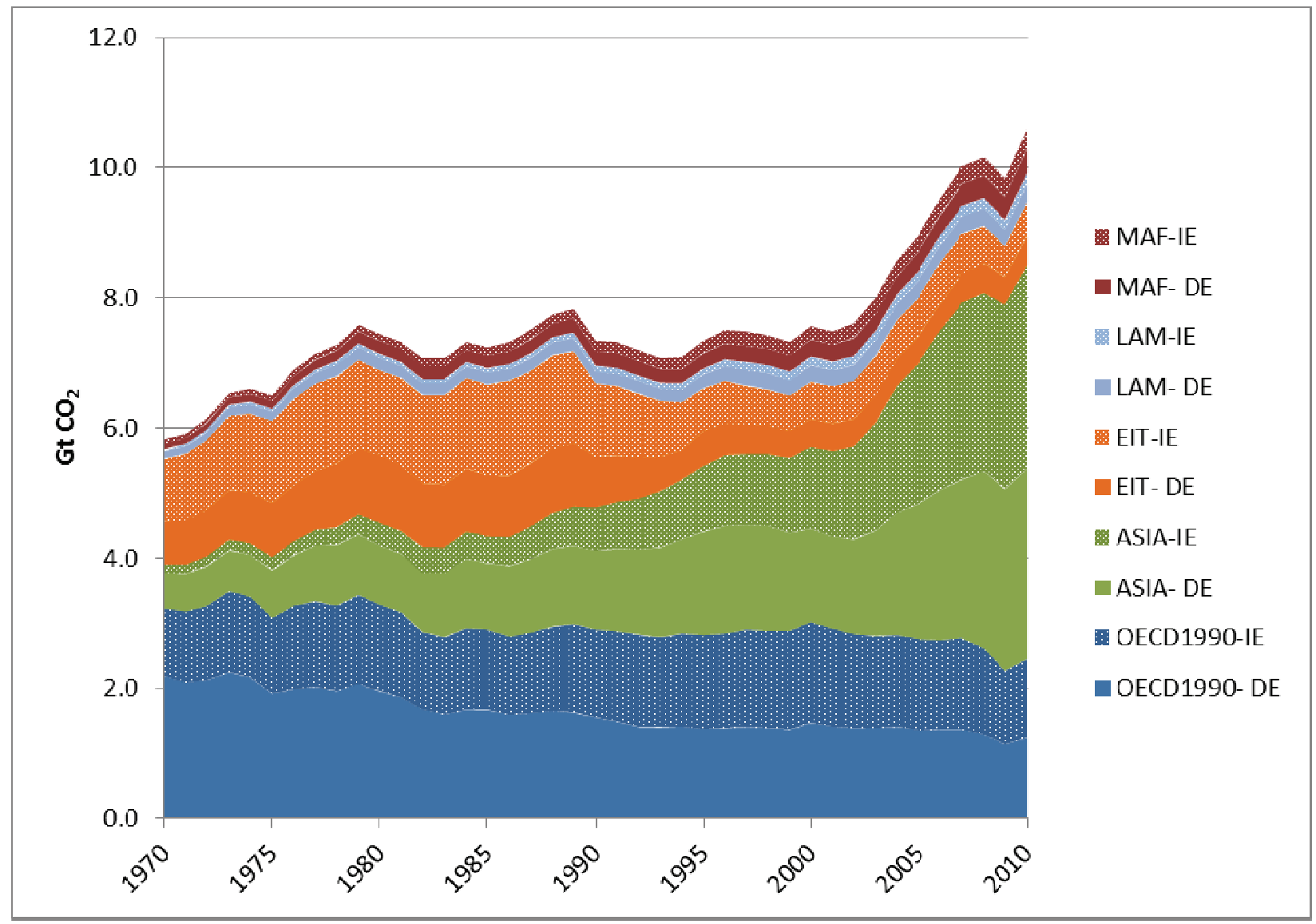

Note: $\mathrm{DE}=$ direct emissions; $\mathrm{IE}=$ indirect emissions; $\mathrm{MAF}=$ Middle East and Africa; LAM = Latin America and Caribbean; EIT = Reforming Economies; ASIA = Asia, OECD1990 = Countries that were members of the OECD in 1990.

Figure 6. Global Energy-Related Direct and Indirect $\mathrm{CO}_{2}$ Emissions from the Industrial Sector by Region, 1970-2010

The ASIA region experienced much faster average annual growth (8.4\%) during the period 2000 to 2010 than during the previous decade (1990-2000), indicating a net acceleration and making this region the largest current source of industrial $\mathrm{CO}_{2}$ emissions from fuel combustion. This is explained largely by the growth of emissions in China, as shown in Figure 7, which presents global industrial $\mathrm{CO}_{2}$ emissions from fuel combustion (direct and indirect combined) for China, USA, the 27 countries of the European Union (EU-27), India, and the rest of the world (ROW). In 2010, China was by far the largest producer of industrial emissions worldwide, followed by the USA and EU-27. Developed and developing countries show opposite trends. Industrial emissions 
in China and India increased by $165 \%$ and $85 \%$, respectively and decreased in the USA and EU27 by $25 \%$ and $17 \%$, respectively. Globally, industrial-sector emissions increased by $40 \%$ during the period 2000-2010.

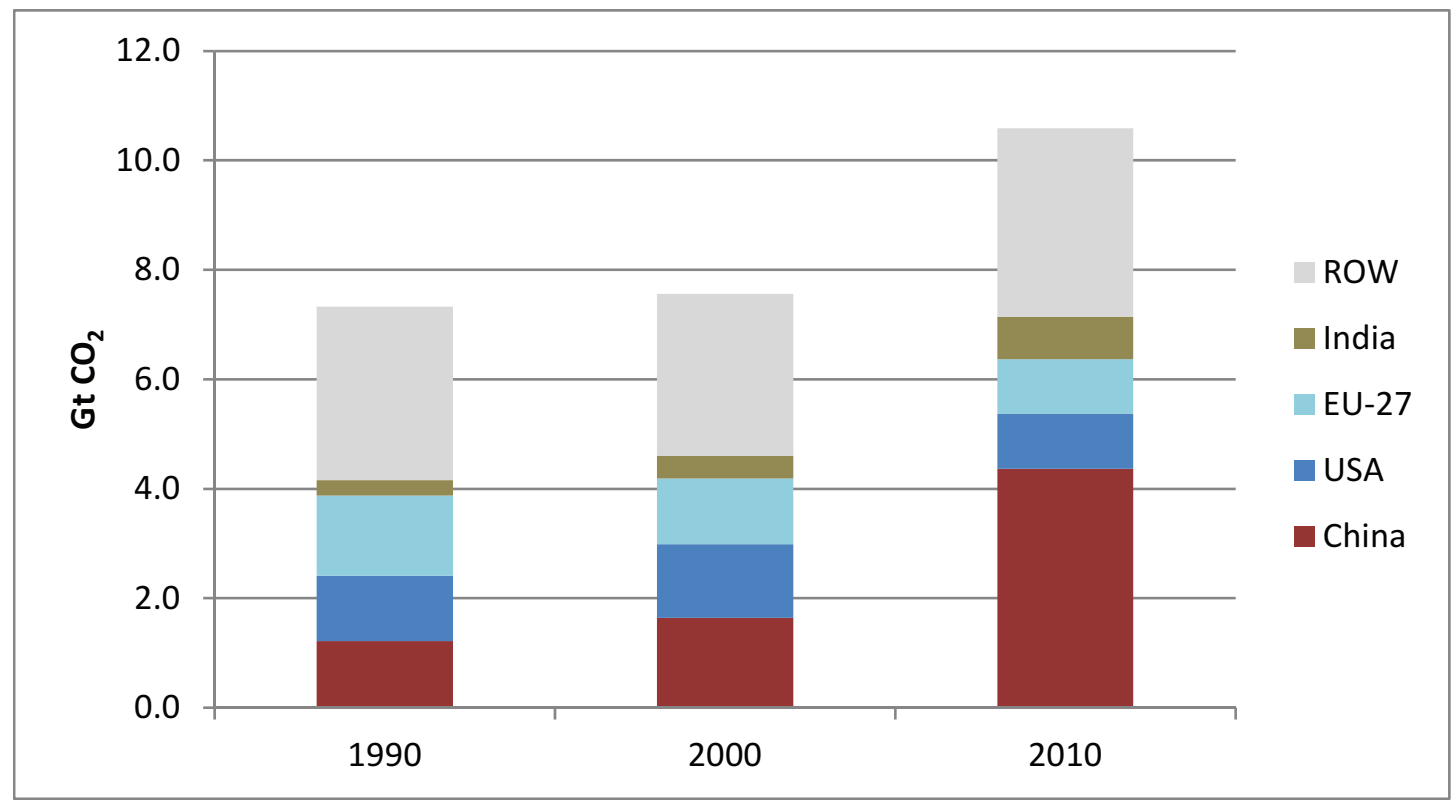

Note: ROW = rest of world; EU = European Union; USA = United States of America

Figure 7. Global Energy-Related Direct and Indirect $\mathrm{CO}_{2}$ Emissions from the Industrial Sector by Region

Emissions from the industrial sector depend on the nature of the industrial technology as well as fuel mix, resource availability, and industrial-sector structure. The industrial sector can be broadly defined as consisting of energy-intensive industries (e.g., iron and steel, chemicals, petroleum refining, cement, aluminum, pulp, and paper) and light industries (e.g., food processing, textiles, wood products, printing and publishing, and metal processing). The share of energy-intensive industry in the total output is a key determinant of the level of total emissions. Countries that have a high share of energy-intensive industry will have higher industrial carbon emissions intensity than will service-based economies. Figure 8 shows global industrial $\mathrm{CO}_{2}$ emissions from fuel combustion (direct and indirect combined) by industry subsectors. The iron and steel sub-sector is the largest sub-sector source of $\mathrm{CO}_{2}$ emissions from fuel combustion with $2.35 \mathrm{GtCO}_{2}$, or $22 \%$, of industrial emissions. Next are the chemical/ petrochemical and non-metallic mineral sub-sectors with emissions of $1.46 \mathrm{GtCO}_{2}(14 \%)$ and $1.24 \mathrm{GtCO}_{2}(12 \%)$, respectively. 


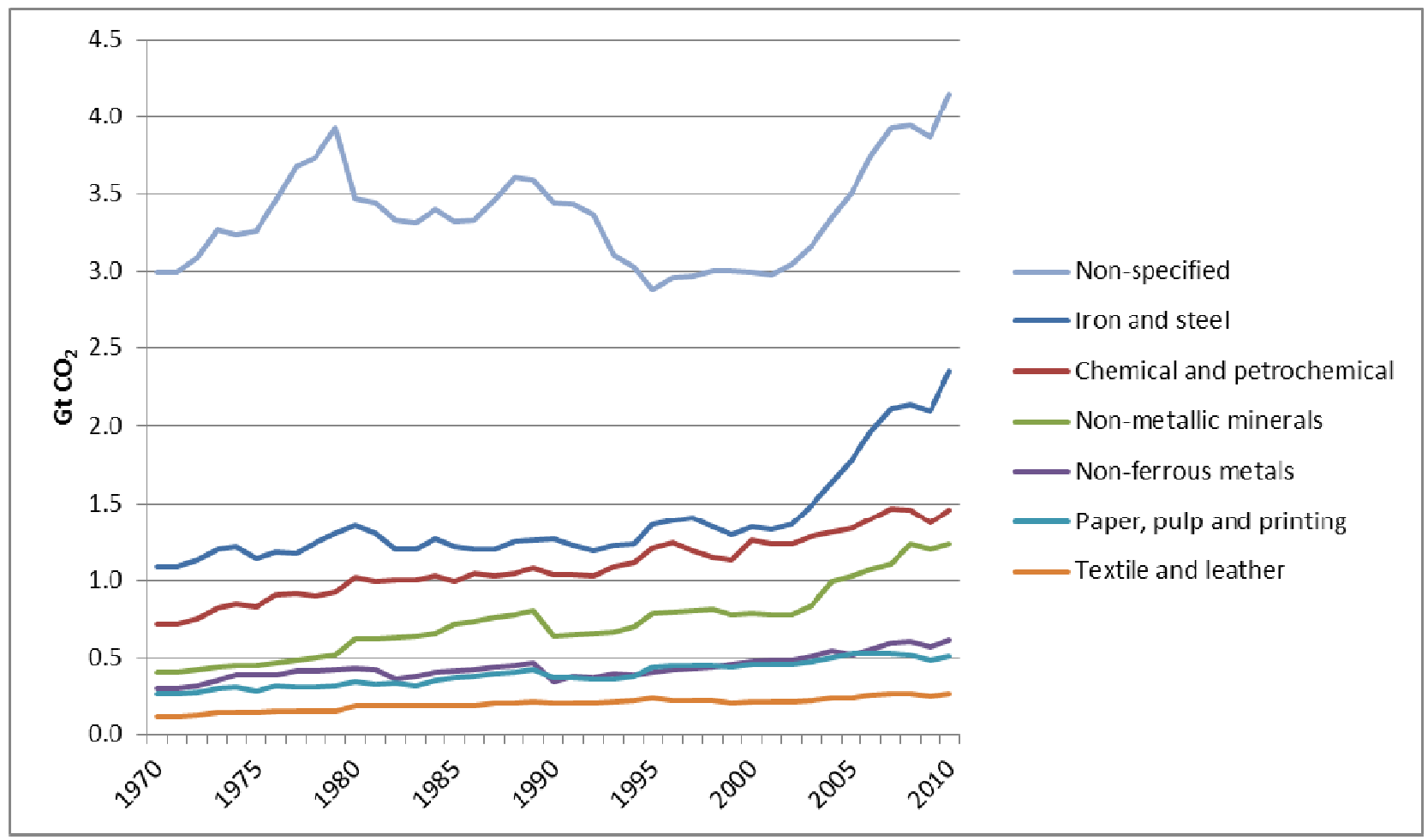

Figure 8. Global Energy-Related Direct and Indirect Industry Emissions by Sub-sector

\subsection{BUILDINGS}

The buildings sector ranks second after the industrial sector as a global source of direct and indirect $\mathrm{CO}_{2}$ emissions, emitting $8.8 \mathrm{GtCO}_{2}$ in 2010. This value represents $95 \%$ of all GHG emissions from that sector ${ }^{4}$ (IPCC, 2014). Emissions from the buildings sector have increased over the last 10 years at an AAGR of $2.1 \%$, slightly faster than during the previous 10 years (1990-2000) when the AAGR was 1.6\%. In 2010, 70\% of total buildings-sector $\mathrm{CO}_{2}$ emissions were indirect emissions because of the large share of electricity in the energy mix in this sector, which increased from $29 \%$ in 1990 to $40 \%$ in $2010^{5}$ (IEA, 2013a). Indirect emissions have an AAGR of $2.8 \%$ compared to $0.7 \%$ for direct emissions over the period 2000 to 2010 because of the rapid increase in electricity use compared to fuel use. Figure 9 shows historical direct and indirect buildings-sector $\mathrm{CO}_{2}$ emissions from fuel combustion for five world regions.

\footnotetext{
${ }^{4}$ Other GHGs from the buildings sector include mostly methane $\left(\mathrm{CH}_{4}\right)$ and nitrous oxide $\left(\mathrm{N}_{2} \mathrm{O}\right)$ from biomass combustion and hydrofluorocarbons (HFCs) from operation and disposal of aerosol, refrigeration, and airconditioning equipment.

${ }^{5}$ Excluding biomass
} 


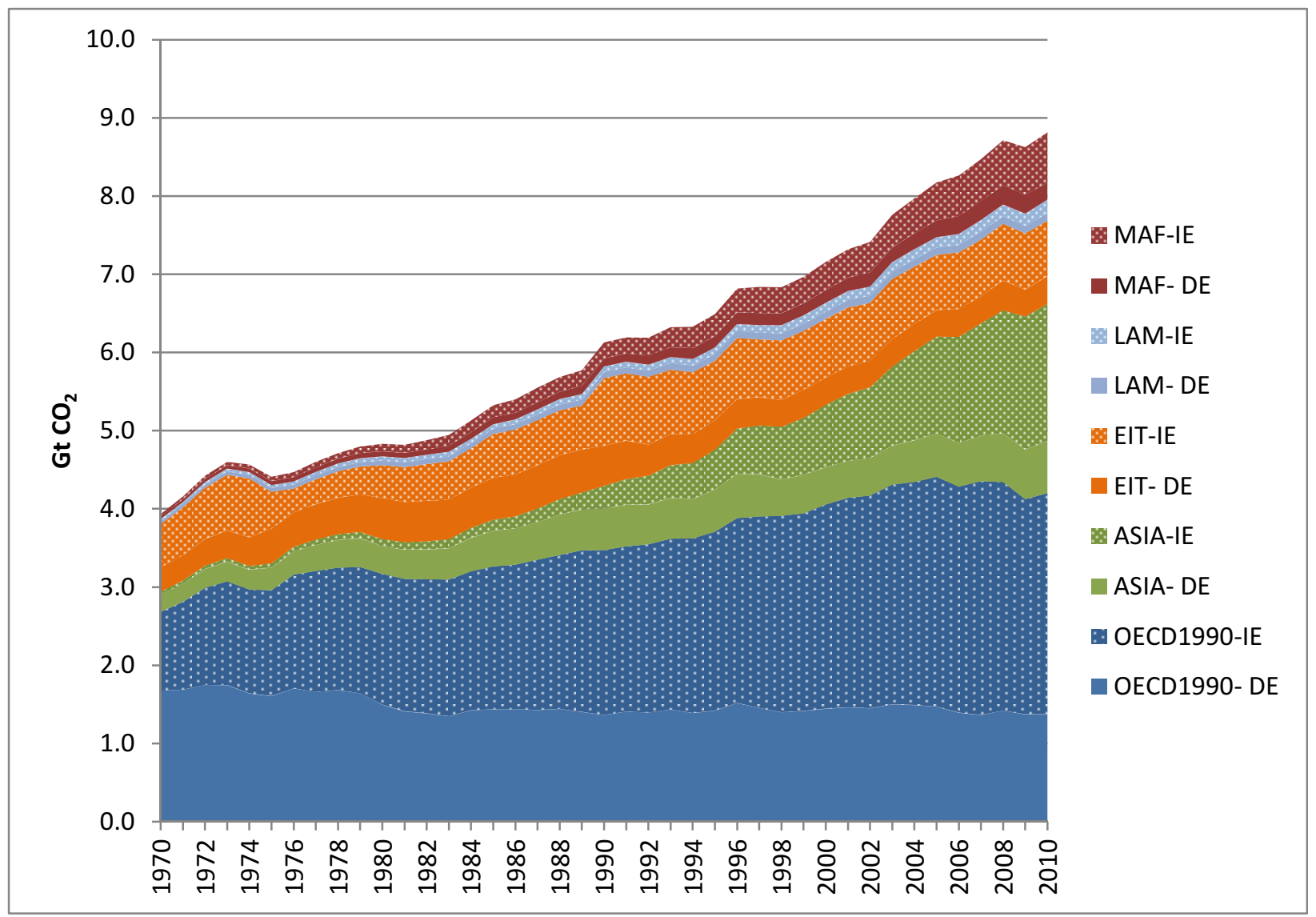

Note: $\mathrm{DE}=$ direct emissions; IE = indirect emissions; $\mathrm{MAF}=$ Middle East and Africa; LAM = Latin America and Caribbean; EIT = Reforming Economies; ASIA = Asia, OECD1990 = Countries that were members of the OECD in 1990.

Figure 9. Global Energy-Related Direct and Indirect $\mathrm{CO}_{2}$ Emissions from the Buildings Sector by Region

The largest regional buildings-sector emissions source is the OECD1990 region, which represents almost half of all buildings $\mathrm{CO}_{2}$ emissions (48\%). Although emissions from fuel use decreased slightly in that region, by an average of $0.5 \%$ per year during the period 2000-2010, this was more than compensated for by the increase in emissions from electricity and heat $(0.8 \%)$ during the same period. The fastest growth in regional emissions was in the ASIA region which had an AAGR of $6.6 \%$ over the period 2000-2010.

At a more regionally disaggregated level (Figure 10), the USA was the largest source of emissions from the buildings sector with $2.27 \mathrm{GtCO}_{2}$, representing more than a quarter of global emissions, followed by the EU-27 and China with 16\% each. 


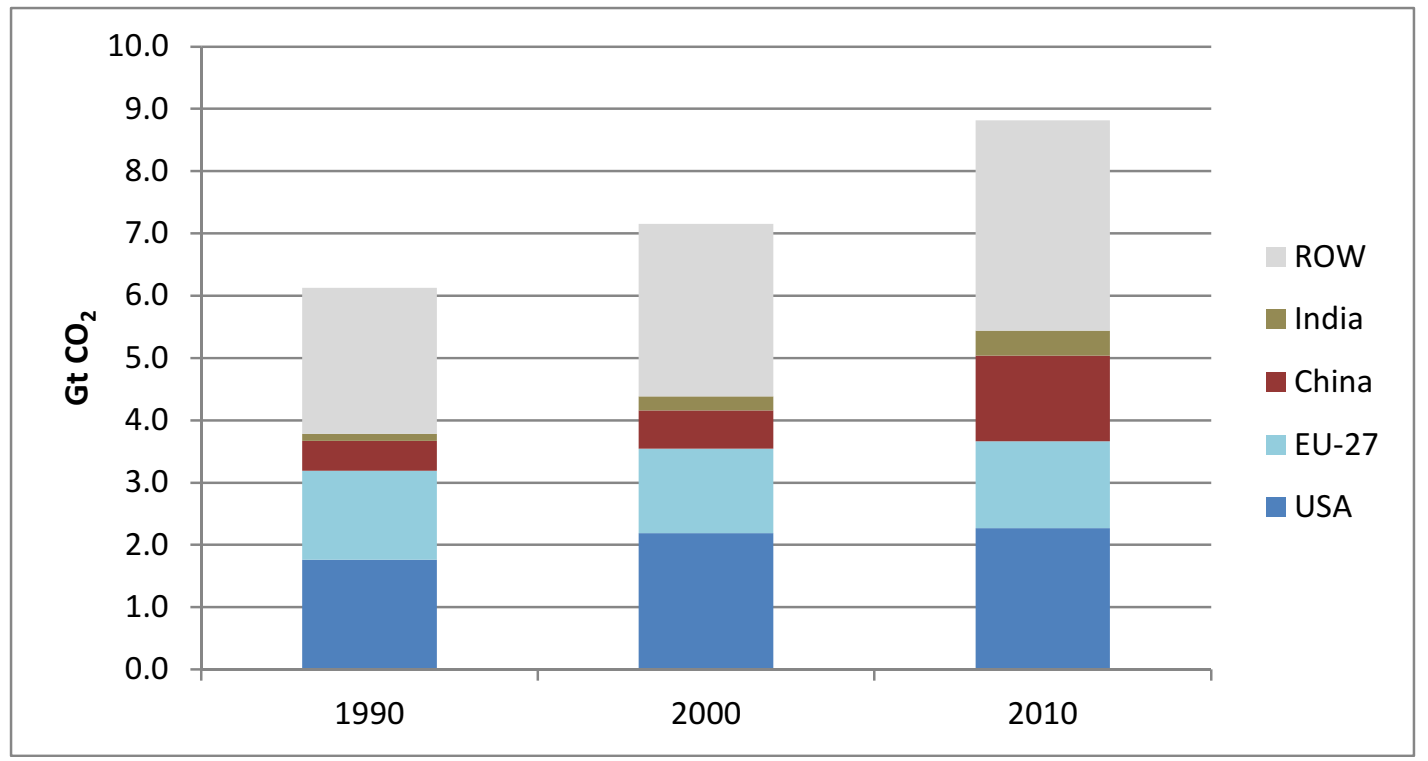

Note: $\mathrm{ROW}=$ rest of world; EU = European Union; USA = United States of America

Figure 10. Global Energy-Related Direct and Indirect $\mathrm{CO}_{2}$ Emissions from the Buildings Sector by Region

The buildings sector is composed of both residential and commercial ${ }^{6}$ buildings (Figure 11). Electricity use has increased considerably in both building types over the last 20 years. This growth is particularly notable in commercial buildings where the share of electricity consumption grew from 17\% of final energy consumed in 1971 to 50\% in 2010 (IEA, 2013b). This growth has been driven by increasing penetration of electrical equipment for space cooling, air ventilation, and lighting, as well as growth in office equipment. Residential sector electricity consumption accounts for a much smaller share (21\%). In developing countries, a large quantity of energy is still used in the form of biomass ${ }^{7}$, which accounts for $40 \%$ of final energy consumption. To date, electricity use in the buildings sector has been largely attributable to developed countries. However, electricity use is expected to grow more rapidly in developing countries in the future as rural populations move to cities and economies become more service-based. Ownership of electricity-consuming appliances in developing countries is increasing rapidly, as shown in McNeil et al. (2013) and IEA (2013c).

\footnotetext{
${ }^{6}$ Also known as the tertiary or the service sector, the commercial buildings sector includes wholesale and retail trade, finance, communications, health care, utilities, and education according to the International Standard Industrial Classification sub-sector rev.4 Code G to U (UN, 2010).

${ }^{7}$ In the IPCC methodology, emissions from the burning of biomass for energy are not included in the $\mathrm{CO}_{2}$ emissions. This is because for the purpose of calculating $\mathrm{CO} 2$ emissions, biomass consumption for fuel is assumed to equal its regrowth. Any departures from this hypothesis are counted within the land use, land use change and forestry module of the 1996 IPCC. (IEA, 2012a)
} 


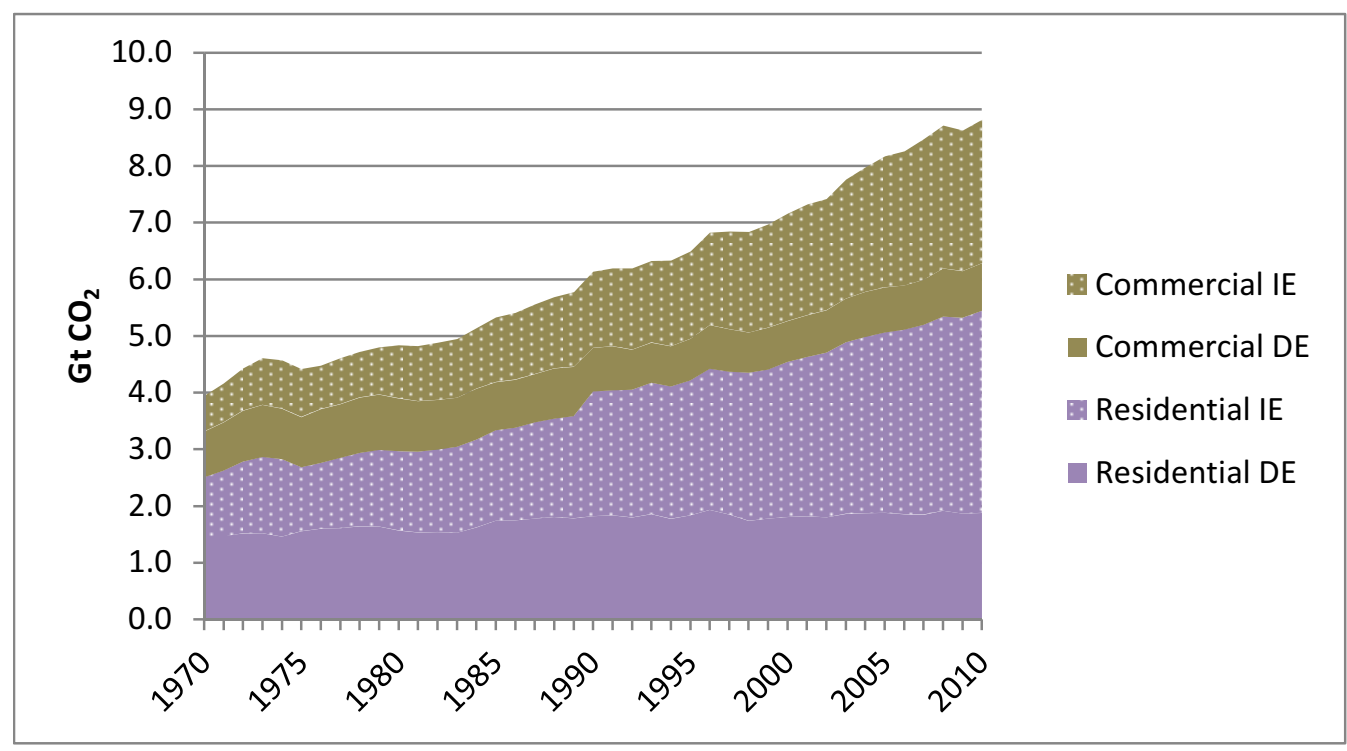

Note: $D E$ = direct emissions; $I E$ = indirect emissions

Figure 11. Global Energy-Related Direct and Indirect Buildings $\mathrm{CO}_{2}$ Emissions by Sub-sector

\subsection{TRANSPORT}

In 2010, emissions from fuel combustion in the transportation sector were $6.87 \mathrm{GtCO}_{2}$, representing $96 \%{ }^{8}$ of all GHG emissions from that sector. Indirect emissions in the transportation sector are very small, only $2 \%$. This is because only a very small quantity of electricity is used for transport, and no heat consumption is reported in this sector. Most of the energy used in this sector is in the form of oil products, which account for $93 \%$ of all energy used with natural gas consuming 4\%, biofuel 2\%, and electricity 1\% (IEA, 2013b). Figure 12 shows historical direct and indirect $\mathrm{CO}_{2}$ emissions from fuel combustion in the transportation sector for five world regions, plus international bunkers. The international bunkers category represents emissions from fuel burned by ships and aircraft of all countries that are engaged in international navigation and aviation.

\footnotetext{
${ }^{8}$ Other GHGs from the transportation sector include mostly methane $\left(\mathrm{CH}_{4}\right)$ and nitrous oxide $\left(\mathrm{N}_{2} \mathrm{O}\right)$ from fuel combustion and hydrofluorocarbons (HFC) from air-conditioning equipment in vehicles.
} 


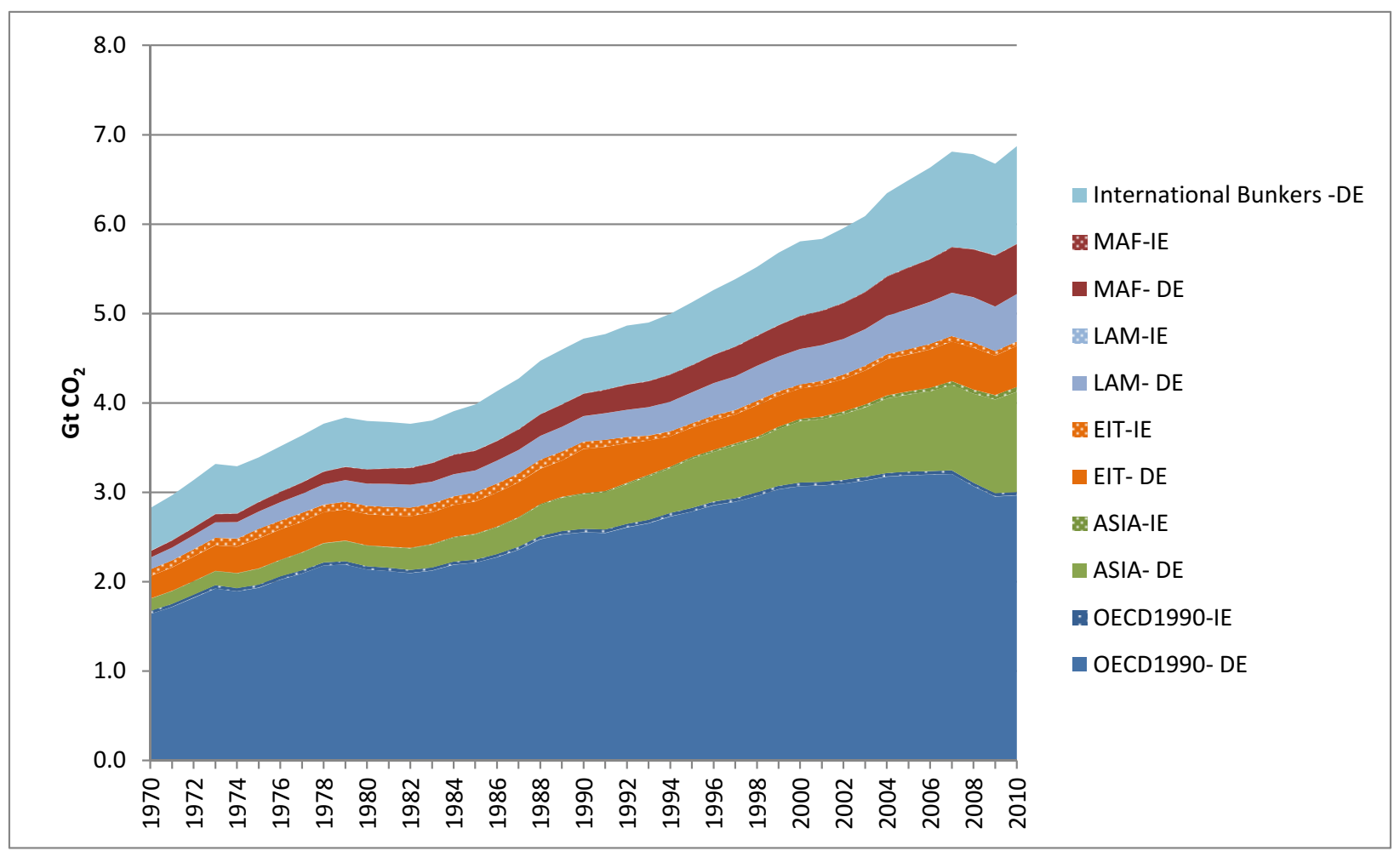

Note: $\mathrm{DE}$ = direct emissions; $\mathrm{IE}=$ indirect emissions; $\mathrm{MAF}=$ Middle East and Africa; LAM = Latin America and Caribbean; EIT = Reforming Economies; ASIA = Asia, OECD1990 = Countries that were members of the OECD in 1990.

Figure 12. Global Energy-Related Direct and Indirect $\mathrm{CO}_{2}$ Emissions from the Transportation Sector by Region

At the country level, the USA is by far the largest source of emissions, accounting for $24 \%$ of all $\mathrm{CO}_{2}$ emissions from fuel combustion in the transportation sector (Figure 13). The next largest sources of emissions are international bunkers and transportation in the EU-27 with $16 \%$ and $13 \%$ of $\mathrm{CO}_{2}$ emissions from fuel combustion, respectively. The remaining emissions are spread among the other countries. The shares of China (8\%) and India (3\%) are relatively small, but this is expected to change as car ownership and freight travel is increasing in these countries (Zhou, 2013; de la Rue du Can, 2009). 


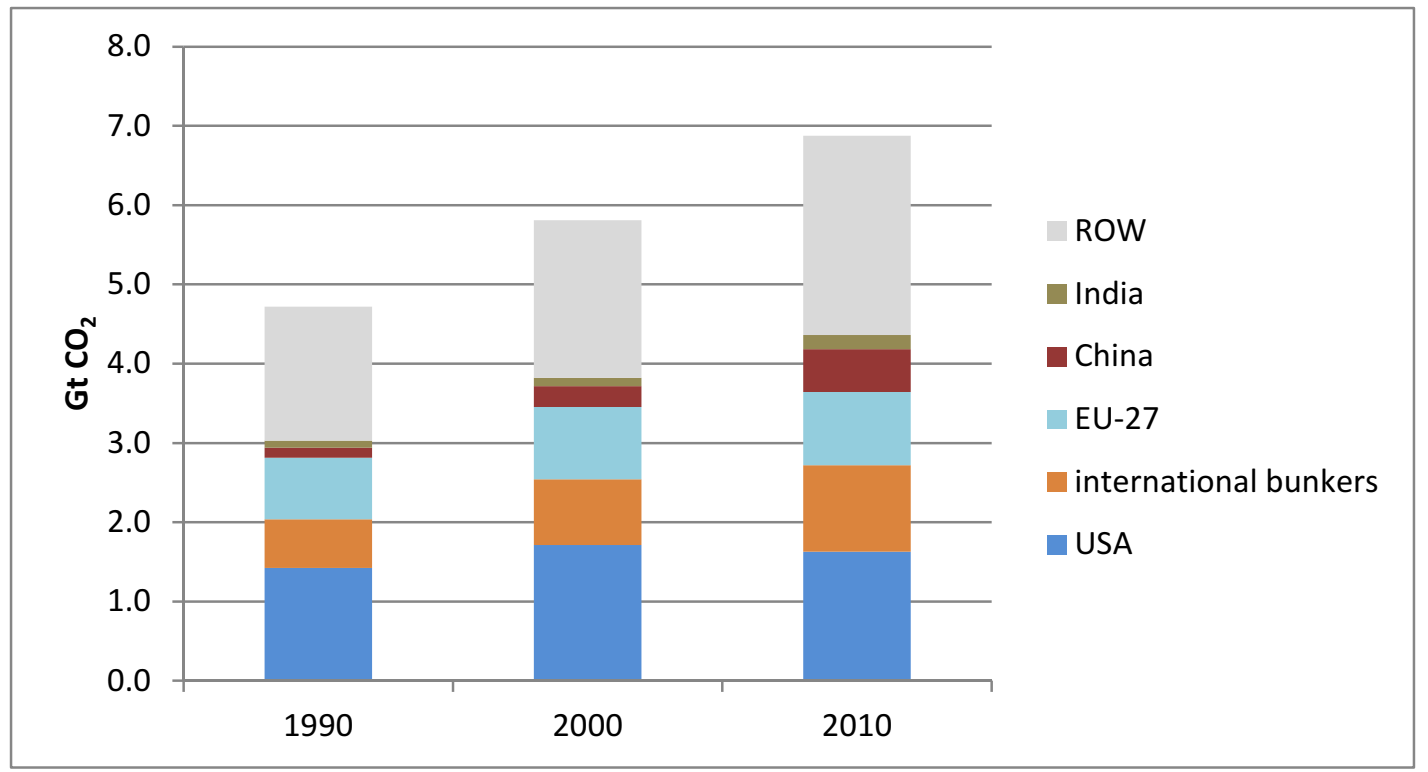

Note: ROW = rest of world; EU = European Union; USA = United States of America

Figure 13. Global Energy-Related Direct and Indirect $\mathrm{CO}_{2}$ Emission from the Transportation Sector by Region

At the sub-sectoral level, emissions from road transportation dominate, accounting for $74 \%$ of all $\mathrm{CO}_{2}$ emissions from fuel combustion. A detailed breakdown between freight and passenger emissions is not available in the IEA energy statistics. It is possible that demand for electricity will increase rapidly in the transportation sector if electric vehicle ownership increases. 


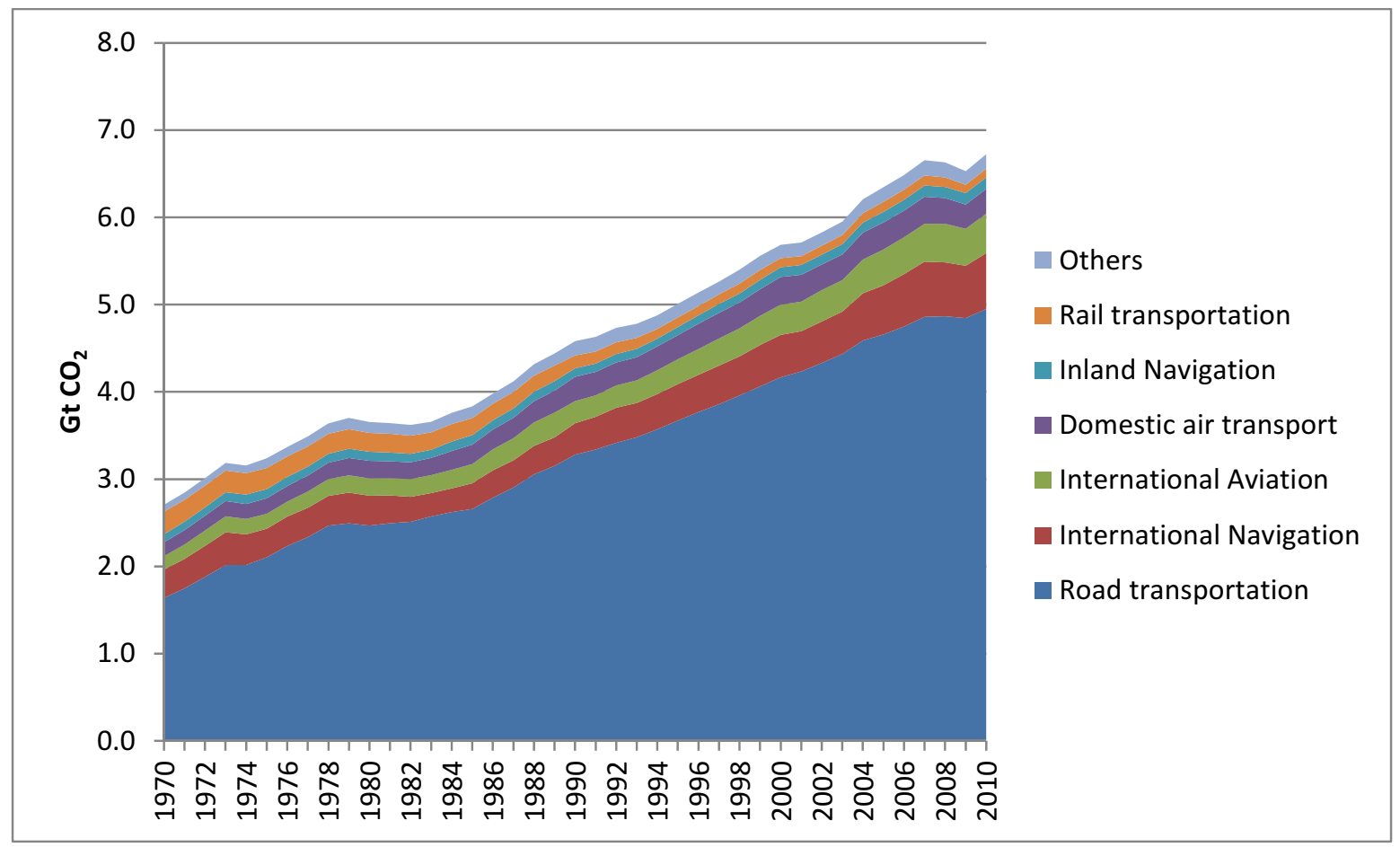

Figure 14. Global Energy-Related Direct and Indirect Transport $\mathrm{CO}_{2}$ Emissions by Sub-sector

\subsection{AgRICULTURE}

According to the IPCC's Fifth Assessment Report, about $25 \%$ of all GHG emissions released into the atmosphere come from the agriculture, forestry, and other land uses (AFOLU) sector. However, most of these emissions originate from sources other than fuel combustion. Fuel combustion accounted for only $8 \%$ of GHG emissions from this sector in 2010 . The main sources of the emissions in this sector are deforestation, agricultural livestock, soil fertilization, and rice cultivation. Of this $8 \%$, indirect emissions represented $44 \%$, reflecting a significant use of electricity in this sector.

\section{DISCUSSION AND CONCLUSIONS}

This paper describes a methodology for accounting for indirect $\mathrm{CO}_{2}$ emissions from electricity and heat consumption in the sectors where these energy products are ultimately consumed. The results show the emissions attributable to energy demand (and use) in each end-use sector. Attributing these indirect emissions to the responsible sectors allows for assessing the full impact of electricity and heating efficiency improvements in the end-use sectors. The results show that when only considering direct $\mathrm{CO}_{2}$ emissions, the largest sector is the energy sector, but when indirect $\mathrm{CO}_{2}$ emissions from electricity and heat production are allocated to 
then end-use sectors that use those energy sources, the industry and buildings sectors dominate overall $\mathrm{CO}_{2}$ emissions.

Production of electricity from fossil fuels is particularly energy intensive and emits substantial $\mathrm{CO}_{2}$ globally. The global emissions intensity of producing and distributing one unit of electricity is the highest of all energy products: $169 \mathrm{tCO}_{2} / \mathrm{TJ}$. Even though there has been a significant increase in electricity production from renewable sources over the last 20 years, this has been offset by the increase in electricity production from carbon-intensive fossil fuels. As a result, the average $\mathrm{CO}_{2}$ emissions factor for delivered electricity has remained flat. Moreover, a significant amount of electricity is lost during transmission and distribution to the end-use sectors.

Accounting for indirect emissions allows for a better understanding of the underlying trends from the demand sectors by linking final energy use and $\mathrm{CO}_{2}$ emissions. This is useful from a policy perspective, as policies to improve energy efficiency often reduce both direct and indirect emissions. There is a need to account for indirect emissions at the sectoral level so that policy makers understand the relative importance of sectoral emissions trends and the link between $\mathrm{CO}_{2}$ emissions as reported to the UNFCCC and the final energy demand driving the source of these emissions. It is important to have a more complete picture of the climate impact of the electricity and heat reduction opportunities in the end-use sectors. This is even more essential when considering sectoral national targets and when pledging reduction commitments in international negotiations. Without accounting for indirect emissions, the impacts of specific efforts to reduce emissions are not fully represented and policy or investment decisions could be made without complete information on the benefits of such actions. Given the pressing nature of global climate change, ensuring that energy and emissions accounting that clearly links all emissions - both direct and indirect - to the end use sectors where the energy is used is essential for informed decision-making regarding investments in energy efficiency.

As a growing number of countries chose to calculate and report indirect emissions, there is a need to develop an internationally recognized method to allocate emissions resulting from the production and distribution of final energy to the sectors where these are ultimately consumed. This paper describes the methodology used in the IPCC's Fifth Assessment Report to initiate and contribute to the effort to develop such an internationally accepted methodology for allocation of indirect emissions to the end-use sectors to better represent their actual emissions and the impact of emissions mitigation efforts taken at the end-use level.

Acknowledgement 
The authors would like to thank Diana Urge Vorsatz from the Central European University and Mark Levine from Lawrence Berkeley National Laboratory (LBNL) for their support, and Michael McNeil from LBNL and Roberta Quadrelli from the International Energy Agency for their thoughtful input and careful review. This work was funded by a Laboratory Directed Research and Development grant under Contract No. DE-AC02-05CH11231. Any errors or omissions are the authors' own.

\section{References}

Bernstein, L., J. Roy, K. C. Delhotal, J. Harnisch, R. Matsuhashi, L. Price, K. Tanaka, E. Worrell, F. Yamba, Z. Fengqi, 2007: Industry.In Climate Change 2007: Mitigation. Contribution of Working Group III to the Fourth Assessment Report of the Intergovernmental Panel on Climate Change [B. Metz, O.R. Davidson, P.R. Bosch, R. Dave, L.A. Meyer (eds)], Cambridge University Press, Cambridge, United Kingdom and New York, NY, USA.

Brander Matthew, Aman Sood, Charlotte Wylie, Amy Haughton, and Jessica Lovell, "Electricityspecific emission factors for grid electricity, Technical Paper, August 2011, ecometrica, http://ecometrica.com/assets/Electricity-specific-emission-factors-for-grid-electricity.pdf

Caro D., S. Bastianoni, S. Borghesi and F. M. Pulselli, 2014. "On the feasibility of a consumerbased allocation method in nationalGHG inventories", Ecological Indicators 36 (2014) 640-643.

Chen Bin and Shaoqing Chen, 2015. Urban metabolism and nexus, Ecological Informatics, Volume 26, Part 1, March 2015, Pages 1-2

Chen S.Q. and B. Chen, 2012. Network environ perspective for urban metabolism and carbon emissions: a case study of Vienna, Austria. Environ. Sci. Technol., 46 (2012), pp. 4498-4506

Davis, S.J., Peters, G.P., and Caldeira, K. (2011) The Supply Chain of $\mathrm{CO}_{2}$ Emissions. PNAS, v. 108, no. 45, p. $18554-18559$.

Davis, S.J. and Caldeira, K. (2010) Consumption-based accounting of $\mathrm{CO}_{2}$ emissions. PNAS, v. 107 , no. 12 , p. $5687-5693$

de la Rue du Can Stephane and Lynn Price, "Sectoral trends in global energy use and greenhouse gas emissions" Energy Policy 36 (2008) 1386-1403.

de la Rue du Can, Stephane, Virginie E. Letschert, Michael A. McNeil, Nan Zhou, and Jayant A. Sathaye. "Residential and Transport Energy Use in India: Past Trend and Future Outlook". LBNL, 2009. Download: PDF (706.8 KB)

European Environment Agency (EEA), 2012. "End-user GHG emissions from energy reallocation of emissions from energy industries to end users 2005-2010". EEA Technical report No 18/2012 
Feng, K.; Davis, S.J. “Outsourcing $\mathrm{CO}_{2}$ within China. PNAS, 2013, 110(28), 11654-11659.

Gavrilova O. and R. Vilu, 2012. "Production-based and consumption-based national greenhouse gas inventories: An implication for Estonia” Ecological Economics 75 (2012) 161-173.

Graus W. and Worrell E., 2011. "Methods for calculating $\mathrm{CO}_{2}$ intensity of power generation and consumption: a global perspective", Energy Policy, 39 (2011), pp. 613-627.

Harmsenn R. and W. Graus, 2013. "How much $\mathrm{CO}_{2}$ emissions do we reduce by saving electricity? A focus on methods", Energy Policy, Volume 60, September 2013, Pages 803-812

Homma T., K. Akimoto and T. Tomoda, 2012. "Quantitative evaluation of time-series GHG emissions by sector and region using consumption-based accounting", Energy Policy 51 (2012) 816-827.

Intergovernmental Panel on Climate Change (IPCC), "2006 IPCC Guidelines for National Greenhouse Gas Inventories", http://www.ipcc-nggip.iges.or.jp/public/2006gl/index.html

Intergovernmental Panel on Climate Change (IPCC), 2014, "Mitigation of Climate Change", Contribution of Working Group III to the Fourth Assessment Report of the Intergovernmental Panel on Climate Change.

International Energy Agency (IEA), 2013a. “CO $\mathrm{CO}_{2}$ Emissions from Fuel Combustion, 1971-2010". Paris: IEA/OECD.

International Energy Agency (IEA), 2013b. "World Energy Statistics". CDrom. Paris: IEA/OECD.

International Energy Agency (IEA), 2013c. "World Energy Outlook”. Paris: IEA/OECD.

Kannan R., Neil Strachan, 2009. "Modelling the UK residential energy sector under long-term decarbonisation scenarios: Comparison between energy systems and sectoral modelling approaches" Applied Energy 86 (2009) 416-428

Krey V., O. Masera, G. Blanford, T. Bruckner, R. Cooke, K. Fisher-Vanden, H. Haberl, E. Hertwich, E. Kriegler, D. Mueller, S. Paltsev, L. Price, S. Schlömer, D. Ürge-Vorsatz, D. P. van Vuuren, and T. Zwickel, 2014: Annex II: Metrics \& Methodology. In: Climate Change 2014: Mitigation of Climate Change. Contribution of Working Group III to the Fifth Assessment Report of the Intergovernmental Panel on Climate Change [Edenhofer, O., R. Pichs-Madruga, Y. Sokona, E. Farahani, S. Kadner, K. Seyboth, A. Adler, I. Baum, S. Brunner, P. Eickemeier, B. Kriemann, J. Savolainen, S. Schlömer, C. von Stechow, T. Zwickel and J.C. Minx (eds.)]. Cambridge University Press, Cambridge, United Kingdom and New York, NY, USA. 
Levine, M., D. Ürge-Vorsatz, K. Blok, L. Geng, D. Harvey, S. Lang, G. Levermore, A. Mongameli Mehlwana, S. Mirasgedis, A. Novikova, J. Rilling, H. Yoshino, 2007: Residential and commercial buildings. In Climate Change 2007: Mitigation. Contribution of Working Group III to the Fourth Assessment Report of the Intergovernmental Panel on Climate Change [B. Metz, O.R. Davidson, P.R. Bosch, R. Dave, L.A. Meyer (eds)], Cambridge University Press, Cambridge, United Kingdom and New York, NY, USA.

McNeil, M., V. Letschert, S. de la Rue du Can and J. Ke. "Bottom-Up Energy Analysis System (BUENAS) - An International Appliance Efficiency Policy Tool”. Energy Efficiency (2013) 6:191217.

Marnay, C., Fisher, D., Murtishaw, S., Phadke, A., Price, L., and Sathaye, J., 2002. Estimating Carbon Dioxide Emission Factors for the California Electric Power Sector. Berkeley, CA: Lawrence Berkeley National Laboratory LBNL-49945. http://emp.lbl.gov/publications/estimating-carbon-dioxide-emissions-factors-californiaelectric-power-sector

Ou X., Y. Xiaoyu, and X. Zhang, 2011. "Life-cycle energy consumption and greenhouse gas emissions for electricity generation and supply in China" Applied Energy 88 (2011) 289-297.

Peters G. P., 2010. “Carbon footprints and embodied carbon at multiple scales” Current Opinion in Environmental Sustainability 2010, 2:245-250.

Shigeto S., Y. Yamagata, R. Ii, M. Hidaka, M. Horio, 2012. “An easily traceable scenario for $80 \%$ $\mathrm{CO}_{2}$ emission reduction in Japan through the final consumption-based $\mathrm{CO} 2$ emission approach: A case study of Kyoto-city" Applied Energy 90 (2012) 201-205.

Sampo Soimakallio and Laura Saikku, 2012. “ $\mathrm{CO}_{2}$ emissions attributed to annual average electricity consumption in OECD (the Organisation for Economic Co-operation and Development) countries", Energy, Volume 38, Issue 1, February 2012, Pages 13-20.United Nations (UN), 2009, "ISIC Rev.4 - International Standard Industrial Classification of All Economic Activities, Rev.4", United Nations Statistics Division, November 2009, http://unstats.un.org/unsd/cr/registry/regcst.asp?Cl=27

UK Department of Energy and Climate Change (DECC), 2014. "2013 UK Greenhouse Gas Emissions, Provisional Figures and 2012 UK Greenhouse Gas Emissions, Final Figures by Fuel Type and End-User"

https://www.gov.uk/government/uploads/system/uploads/attachment_data/file/295968/2014 0327_2013_UK_Greenhouse_Gas_Emissions_Provisional_Figures.pdf 
US Environmental Protection Agency, "Inventory of U.S. Greenhouse Gas Emissions and Sinks: 1990-2012" (April 2014) http://epa.gov/climatechange/Downloads/ghgemissions/US-GHGInventory-2014-Chapter-2-Trends.pdf

Yuan B., S. Ren, X. Chen, 2015. "The effects of urbanization, consumption ratio and consumption structure on residential indirect $\mathrm{CO}_{2}$ emissions in China: A regional comparative analysis" Applied Energy 140 (2015) 94-106

Zhou, N., D. Fridley, N.Z. Khanna, J. Ke, M.A.McNeil and M. Levine. "China's Energy and Emissions Outlook to 2050: Perspectives from Bottom-up Energy End-use Model." Energy Policy 53 (2013) 51-62. 


\section{Appendix A: Carbon Coefficients}

\begin{tabular}{|c|c|}
\hline SOLID FOSSIL & tC/TJ \\
\hline Hard Coal & 25.8 \\
\hline Brown Coal & 26.85 \\
\hline Coking Coal & 25.8 \\
\hline Other Bituminous Coal \& Anthracite & 25.8 \\
\hline Sub-Bituminous Coal & 26.2 \\
\hline Lignite & 27.6 \\
\hline Peat & 28.9 \\
\hline Patent Fuel & 25.8 \\
\hline Coke Oven Coke & 29.5 \\
\hline Gas Coke & 29.5 \\
\hline Coal Tars & 28 \\
\hline Brown Coal Briquettes & 25.8 \\
\hline Gas Works Gas & 15.3 \\
\hline Coke Oven Gas & 13 \\
\hline Blast Furnace Gas & 66 \\
\hline Oxygen Steel Furnace Gas & 66 \\
\hline \multicolumn{2}{|l|}{ GASEOUS FOSSIL } \\
\hline Natural Gas & 15.3 \\
\hline \multicolumn{2}{|l|}{ LIQUID FOSSIL } \\
\hline Crude & 20 \\
\hline Crude Oil & 20 \\
\hline Natural Gas Liquids & 17.2 \\
\hline Refinery Feedstocks & 20 \\
\hline Additives/Blending Components & 20 \\
\hline \multicolumn{2}{|l|}{ Input of Origin not Crude or Natural Gas } \\
\hline Liquid & 20 \\
\hline Refinery Gas & 18.2 \\
\hline Ethane & 16.8 \\
\hline Liquefied Petroleum Gases & 17.2 \\
\hline Motor Gasoline & 18.9 \\
\hline Aviation Gasoline & 18.9 \\
\hline Gasoline type Jet Fuel & 18.9 \\
\hline Kerosene type Jet Fuel & 19.5 \\
\hline Kerosene & 19.6 \\
\hline Gas/Diesel Oil & 20.2 \\
\hline Residual Fuel Oil & 21.1 \\
\hline Naphtha & 20 \\
\hline White Spirit & 20 \\
\hline Lubricants & 20 \\
\hline Bitumen & 22 \\
\hline Paraffin Waxes & 20 \\
\hline Petroleum Coke & 27.5 \\
\hline Non-specified Petroleum Products & 20 \\
\hline Non-specified Comb. Fuels for Heat & \\
\hline Production & 20 \\
\hline \multicolumn{2}{|l|}{ BIOMASS } \\
\hline Combustible Renewables and Waste & 29.9 \\
\hline Solid Biomass and Animal Products & 29.9 \\
\hline Industrial Waste & 29.9 \\
\hline Municipal Waste & 29.9 \\
\hline Gas/Liquids from Biomass + Wastes & 25.3 \\
\hline Non-specified Combust. Renewables + Wastes & 29.9 \\
\hline
\end{tabular}




\section{Appendix B: Country Mapping and Regional Coverage}

The source data was remapped between countries to have a constant set of countries cover the entire timespan (1970-2010). This affected data of countries belonging to the former Soviet Union (Armenia, Azerbaijan, Belarus, Estonia, Georgia, Kazakhstan, Kyrgyzstan, Latvia, Lithuania, Republic of Moldova, Russian Federation, Tajikistan, Turkmenistan, Ukraine, Uzbekistan) and former Yugoslavia (Bosnia and Herzegovina, Croatia, Kosovo, FYR of Macedonia, Montenegro, Serbia, Slovenia). For those years where the respective individual countries did not yet exist, data was distributed according to the share each country had in the first year of individual data. In a few cases of splitting Serbia data from the period 1990-1999 between Kosovo, Montenegro and Serbia data did not exist for all three countries in the reference year 2000. In those cases earlier data was redistributed according to the size of population in 2000. Additionally, 1970 data were linearly interpolated using 1971 and 1972 data for all non-OECD countries.

The resulting country groupings are as follows:

OECD1990 (OECD1990 countries): Australia, Austria, Belgium, Canada, Denmark, Finland, France, Germany, Gibraltar, Greece, Iceland, Ireland, Italy, Japan, Luxembourg, Netherlands, New Zealand, Norway, Portugal, Spain, Sweden, Switzerland, Turkey, United Kingdom, and United States.

EIT (Economies in Transition): Albania, Armenia, Azerbaijan, Belarus, Bosnia and Herzegovina, Bulgaria, Croatia, Cyprus, Czech Republic, Estonia, Georgia, Hungary, Kazakhstan, Kyrgyzstan, Latvia, Lithuania, Macedonia, Malta, Moldova (Republic of), Montenegro, Poland, Romania, Russian Federation, Serbia, Slovakia, Slovenia, Tajikistan, Turkmenistan, Ukraine, and Uzbekistan.

LAM (Latin America and Caribbean): Argentina, Bolivia, Brazil, Chile, Colombia, Costa Rica, Cuba, Dominican Republic, Ecuador, El Salvador, Guatemala, Haiti, Honduras, Jamaica, Mexico, Netherlands Antilles, Nicaragua, Panama, Paraguay, Peru, Trinidad and Tobago, Uruguay, and Venezuela.

MAF (Middle East and Africa): Algeria, Angola, Bahrain, Benin, Botswana, Cameroon, Congo, Congo (The Democratic Republic of the), Cote d'Ivoire, Egypt, Eritrea, Ethiopia, Gabon, Ghana, Iran, Iraq, Israel, Jordan, Kenya, Kuwait, Lebanon, Libya, Mali, Morocco, Mozambique, Namibia, Nigeria, Oman, Qatar, Saudi Arabia, Senegal, South Africa, Sudan, Syrian Arab Republic, Tanzania, Togo, Tunisia, United Arab Emirates, Yemen, Zambia, and Zimbabwe. 
ASIA (Asia without Japan): Bangladesh, Brunei Darussalam, Cambodia, China, Hong Kong, India, Indonesia, Korea (Democratic People's Republic of), Malaysia, Mongolia, Myanmar, Nepal, Pakistan, Philippines, Singapore, South Korea, Sri Lanka, Taiwan, Thailand and Viet Nam. 
Appendix C: $2010 \mathrm{CO}_{2}$ Electricity Emission Factor per Country in gCO2/kWhand ktCO2/PJ

\begin{tabular}{|c|c|c|c|}
\hline \multirow[t]{2}{*}{ Country } & \multicolumn{2}{|c|}{ Electricity Emission Factor } & \multirow{2}{*}{$\begin{array}{r}\text { Heat Emission Factor } \\
k \mathrm{ktCO} / \mathrm{PJ}\end{array}$} \\
\hline & gCO2/kWh & ktCO2/PJ & \\
\hline Albania & 2.48 & 0.69 & \\
\hline Algeria & 738.83 & 205.23 & \\
\hline Angola & 523.08 & 145.3 & \\
\hline Argentina & 443.81 & 123.28 & \\
\hline Armenia & 109.08 & 30.3 & 70.13 \\
\hline Australia & 979.87 & 272.19 & \\
\hline Austria & 194.62 & 54.06 & 49.68 \\
\hline Azerbaijan & 579.96 & 161.1 & 64.73 \\
\hline Bahrain & 710.85 & 197.46 & \\
\hline Bangladesh & 645.02 & 179.17 & \\
\hline Belarus & 501.04 & 139.18 & 72.19 \\
\hline Belgium & 208.71 & 57.98 & 59.22 \\
\hline Benin & 726.98 & 201.94 & \\
\hline Bolivia & 487.43 & 135.4 & \\
\hline Bosnia and Herzegovina & 866.59 & 240.72 & 144.86 \\
\hline Botswana & 3073.5 & 853.75 & \\
\hline Brazil & 106.73 & 29.65 & \\
\hline Brunei Darussalam & 836.41 & 232.34 & \\
\hline Bulgaria & 664.22 & 184.51 & 100.72 \\
\hline Cambodia & 1189.18 & 330.33 & \\
\hline Cameroon & 253.64 & 70.46 & \\
\hline Canada & 219.7 & 61.03 & 63.69 \\
\hline Chile & 471.14 & 130.87 & \\
\hline China (including Hong Kong) & 876.69 & 243.53 & 118.36 \\
\hline Chinese Taipei & 684.79 & 190.22 & \\
\hline Colombia & 217.03 & 60.29 & \\
\hline Congo & 169.8 & 47.17 & \\
\hline Costa Rica & 63.35 & 17.6 & \\
\hline Cote d'Ivoire & 587.23 & 163.12 & \\
\hline Croatia & 285.14 & 79.2 & 87 \\
\hline Cuba & 1294.97 & 359.71 & \\
\hline Cyprus & 774.89 & 215.25 & \\
\hline Czech Republic & 670.3 & 186.19 & 127.94 \\
\hline Democratic Republic of Congo & 3.29 & 0.92 & \\
\hline Denmark & 380.07 & 105.57 & 63.82 \\
\hline Dominican Republic & 687.98 & 191.11 & \\
\hline Ecuador & 609.06 & 169.18 & \\
\hline Egypt & 523.58 & 145.44 & \\
\hline El Salvador & 272.77 & 75.77 & \\
\hline Eritrea & 790.08 & 219.47 & \\
\hline Estonia & 1184.85 & 329.12 & 73.87 \\
\hline
\end{tabular}




\begin{tabular}{|c|c|c|c|}
\hline \multirow[t]{2}{*}{ Country } & \multicolumn{2}{|c|}{ Electricity Emission Factor } & \multirow{2}{*}{$\begin{array}{l}\text { Heat Emission Factor } \\
k \mathrm{ktCO} 2 / \mathrm{PJ}\end{array}$} \\
\hline & $\mathrm{gCO} / \mathrm{kWh}$ & $\mathrm{ktCO} 2 / \mathrm{PJ}$ & \\
\hline Ethiopia & 9.2 & 2.55 & \\
\hline Finland & 234.49 & 65.13 & 69 \\
\hline Former Yugoslav Republic of Macedonia & 925.66 & 257.13 & 85.95 \\
\hline France & 81.15 & 22.54 & 69.11 \\
\hline Gabon & 502.09 & 139.47 & \\
\hline Georgia & 76.64 & 21.29 & 70.13 \\
\hline Germany & 500.04 & 138.9 & 81.98 \\
\hline Ghana & 345.69 & 96.02 & \\
\hline Gibraltar & 810.56 & 225.16 & \\
\hline Greece & 840.63 & 233.51 & 125.87 \\
\hline Guatemala & 338.57 & 94.05 & \\
\hline Haiti & 557.32 & 154.81 & \\
\hline Honduras & 443.86 & 123.29 & \\
\hline Hong Kong, China & 842.69 & 234.08 & \\
\hline Hungary & 371.54 & 103.2 & 91.86 \\
\hline Iceland & 0.2 & 0.05 & \\
\hline India & 1303.22 & 362.01 & \\
\hline Indonesia & 826.35 & 229.54 & \\
\hline Iraq & 1012.07 & 281.13 & \\
\hline Ireland & 523.02 & 145.28 & \\
\hline Islamic Republic of Iran & 690.48 & 191.8 & \\
\hline Israel & 759.57 & 210.99 & \\
\hline Italy & 440.88 & 122.47 & 73.37 \\
\hline Jamaica & 914.67 & 254.07 & \\
\hline Japan & 454.07 & 126.13 & 37.32 \\
\hline Jordan & 765.78 & 212.72 & \\
\hline Kazakhstan & 507.83 & 141.06 & 133.32 \\
\hline Kenya & 331.54 & 92.1 & \\
\hline Korea & 579.3 & 160.92 & 87.23 \\
\hline Korea, DPR & 634.84 & 176.34 & \\
\hline Kuwait & 1128.47 & 313.46 & \\
\hline Kyrgyzstan & 73.01 & 20.28 & 85.07 \\
\hline Latvia & 119.39 & 33.16 & 67.4 \\
\hline Lebanon & 812.52 & 225.7 & \\
\hline Libya & 1205.67 & 334.91 & \\
\hline Lithuania & 424.33 & 117.87 & 52.43 \\
\hline Luxembourg & 372.96 & 103.6 & 63.34 \\
\hline Malaysia & 832.27 & 231.19 & \\
\hline Malta & 1159.43 & 322.06 & \\
\hline Mexico & 577.2 & 160.33 & \\
\hline Mongolia & 1160.69 & 322.41 & 129.56 \\
\hline Montenegro & 514 & 142.78 & \\
\hline
\end{tabular}




Country
Morocco
Mozambique
Myanmar
Namibia
Nepal
Netherlands
Netherlands Antilles
New Zealand
Nicaragua
Nigeria
Norway
Oman
Pakistan
Panama
Paraguay
Peru
Philippines
Poland
Portugal
Qatar
Republic of Moldova
Romania
Russian Federation
Saudi Arabia
Senegal
Serbia
Singapore
Slovak Republic
Slovenia
South Africa
Spain
Sri Lanka
Sudan
Sweden
Switzerland
Syrian Arab Republic
Tajikistan
Thailand
Togo
Tuninidad and Tobag

\begin{tabular}{|c|c|c|}
\hline \multicolumn{2}{|c|}{ Electricity Emission Factor } & \multirow{2}{*}{$\begin{array}{l}\text { Heat Emission Factor } \\
k \mathrm{ktCO} 2 / \mathrm{PJ}\end{array}$} \\
\hline gCO2/kWh & ktCO2/PJ & \\
\hline 790.49 & 219.58 & \\
\hline 0.72 & 0.2 & \\
\hline 317.49 & 88.19 & \\
\hline 266.47 & 74.02 & \\
\hline 1.08 & 0.3 & \\
\hline 416.78 & 115.77 & 87.6 \\
\hline 957.08 & 265.86 & \\
\hline 168.64 & 46.85 & \\
\hline 686.6 & 190.72 & \\
\hline 509.79 & 141.61 & \\
\hline 16.85 & 4.68 & 18.39 \\
\hline 1012.96 & 281.38 & \\
\hline 524.64 & 145.73 & \\
\hline 351.92 & 97.75 & \\
\hline 0 & & \\
\hline 329.85 & 91.62 & \\
\hline 599.05 & 166.4 & \\
\hline 936.83 & 260.23 & 109.99 \\
\hline 275.13 & 76.42 & 73.43 \\
\hline 567.64 & 157.68 & \\
\hline 529.19 & 147 & 80.57 \\
\hline 498.98 & 138.61 & 107.86 \\
\hline 403.92 & 112.2 & 84.11 \\
\hline 837.25 & 232.57 & \\
\hline 810.21 & 225.06 & \\
\hline 1037.83 & 288.29 & 100.46 \\
\hline 519.05 & 144.18 & \\
\hline 213.87 & 59.41 & 88.53 \\
\hline 370.93 & 103.03 & 109.44 \\
\hline 1096.31 & 304.53 & \\
\hline 256.34 & 71.21 & \\
\hline 450.19 & 125.05 & \\
\hline 446.04 & 123.9 & \\
\hline 23.44 & 6.51 & 27.29 \\
\hline 4.78 & 1.33 & 17.97 \\
\hline 817.39 & 227.05 & \\
\hline 15.32 & 4.25 & 70.13 \\
\hline 575.48 & 159.86 & \\
\hline 198.88 & 55.25 & \\
\hline 771.3 & 214.25 & \\
\hline 560.56 & 155.71 & \\
\hline 566.08 & 157.25 & 71.55 \\
\hline
\end{tabular}




Country
Turkmenistan
Ukraine
United Arab Emirates
United Kingdom
United Republic of Tanzania
United States
Uruguay
Uzbekistan
Venezuela
Vietnam
Yemen
Zambia
Zimbabwe

\begin{tabular}{|c|c|c|}
\hline \multicolumn{2}{|c|}{ Electricity Emission Factor } & \multirow{2}{*}{$\begin{array}{r}\text { Heat Emission Factor } \\
k \mathrm{ktCO} 2 / \mathrm{PJ}\end{array}$} \\
\hline $\mathrm{gCO} / \mathrm{kWh}$ & $\mathrm{ktCO} / \mathrm{PJ}$ & \\
\hline 1198.65 & 332.96 & 70.13 \\
\hline 476.28 & 132.3 & 77.63 \\
\hline 672 & 186.67 & \\
\hline 518.15 & 143.93 & 101.31 \\
\hline 421.79 & 117.16 & \\
\hline 591.38 & 164.27 & 88.22 \\
\hline 94.2 & 26.17 & \\
\hline 628.44 & 174.57 & 84.51 \\
\hline 348.5 & 96.8 & \\
\hline 504.17 & 140.05 & \\
\hline 1017.82 & 282.73 & \\
\hline 3.67 & 1.02 & \\
\hline 752.93 & 209.15 & \\
\hline
\end{tabular}

